\title{
U-Pb LA-(MC)-ICP-MS dating of rutile: new reference materials and applications to sedimentary provenance
}

\author{
Laura Braccialia,b,* \\ Randall R. Parrish ${ }^{\mathrm{a}, \mathrm{c}}$ \\ Matthew S.A. Horstwood ${ }^{\mathrm{a}}$ \\ Daniel Condon $^{\mathrm{a}}$ \\ Yani Najman ${ }^{\mathrm{b}}$
}

${ }^{a}$ NERC Isotope Geosciences Laboratory, British Geological Survey, Keyworth, Nottingham, United Kingdom

${ }^{\mathrm{b}}$ Lancaster Environment Centre, Lancaster University, Lancaster, United Kingdom

${ }^{c}$ Department of Geology, University of Leicester, Leicester, UK

* Corresponding author at: NERC Isotope Geosciences Laboratory, British Geological Survey, Keyworth, Nottingham, NG12 5GG, UK. Tel: +44 (0)115 9363278.

E-mail address: laur@bgs.ac.uk (L. Bracciali).

\begin{abstract}
In response to the general lack of sufficiently abundant and high quality rutile $\mathrm{U}-\mathrm{Pb}$ reference materials for in situ geochronology, we have characterised two new potential rutile $\sim 1.8 \mathrm{Ga}$ reference materials (Sugluk-4 and PCA-S207) from granulite facies belts of the Canadian Shield, namely the northern Cape Smith Belt of Quebec and the Snowbird Tectonic Zone (Sasatchewan). Characterisation includes ID-TIMS and LA-ICP-MS U-Pb dating, imaging, and trace element analysis. We compare these materials with existing rutiles used already (R19 and R10; Luvizotto et al., 2009; Zack et al., 2011) and show that the measured U-Pb compositions (i.e. including any common $\mathrm{Pb}$ ) of our rutiles are considerably more homogeneous. This makes possible a $\mathrm{U}-\mathrm{Pb}$ normalisation procedure (not reliant upon a common $\mathrm{Pb}$ correction) that results in a significant decrease in the uncertainty contribution from the common $\mathrm{Pb}$ correction and better reproducibility of reference materials and
\end{abstract}


unknowns for provenance analysis and other applications. The reproducibility is $2-4 \%$ (2RSD) for ${ }^{206} \mathrm{~Pb} /{ }^{238} \mathrm{U}$ and ${ }^{207} \mathrm{~Pb} /{ }^{206} \mathrm{~Pb}$, only slightly greater than long-term data for zircon reference materials. We show in a rutile provenance study from young orogens (Bhutan Himalaya and Canadian Cordillera) that the sensitivity of our analytical set-up allows dating of $\sim 90 \%$ of rutiles in a sediment using a $50 \mu \mathrm{m}$ laser ablation spotsize within samples containing rutile as young as 10-20 Ma, and obviates the requirement for $\mathrm{U}$ concentration pre-screening, thus reducing or eliminating rutile selection bias. Unsuccessful analyses are due to poor quality rutiles with predominant common $\mathrm{Pb},{ }^{207} \mathrm{~Pb}$ signal below detection, or $\mathrm{U}$ content below $\sim 1-2$ ppm. We have used the ${ }^{6207} \mathrm{~Pb}$-method' (using the Tera-Wasserburg diagram) to correct for substantial common $\mathrm{Pb}$ in very young and/or very low-U rutiles, rather than developing an on-line correction. Since rutile ages reflect mainly the time of cooling, rutile is a sensitive recorder of metamorphic thermochronological information and therefore is an excellent complement to detrital zircon $\mathrm{U}-\mathrm{Pb}$ data. The contrast between zircon and rutile signatures in Himalayan samples with rutile as young as $10 \mathrm{Ma}$ is shown to be very dramatic (most zircons from the same sample are > $480 \mathrm{Ma}$, with only a few grains or metamorphic rims reflecting Miocene metamorphism); as such rutile provides complementary information about the thermal events within the source regions of the grains. Rutile U-Pb dating is an underexploited provenance method with wide applicability to sedimentary provenance studies.

\section{Keywords}

Rutile U-Pb dating, LA-MC-ICP-MS, detrital thermochronology, sedimentary provenance, Sugluk-4, common $\mathrm{Pb}$ correction

\section{Introduction}

Rutile, the most common polymorph of $\mathrm{TiO}_{2}$, is a widely distributed accessory mineral in medium- to high-grade metamorphic and some igneous, chiefly plutonic, rocks. Due to its chemical and physical stability during the sedimentary cycle, rutile is commonly found in the heavy mineral suite of sedimentary rocks and can therefore provide important information about provenance. Rutile typically consists of $>98$ wt $\% \mathrm{TiO}_{2}$, but considerable amounts of other elements such as $\mathrm{Fe}, \mathrm{Cr}, \mathrm{Nb}$ and $\mathrm{Ta}$ and other HFSE (high field strength elements) can enter the crystalline lattice, allowing insight into rock forming conditions and discrimination between different source lithologies in provenance studies (e.g., Zack et al., 2004a; Carruzzo et al., 2006; Triebold et al., 2007; Meinhold et al., 2008; Morton and Chenery, 2009; Ewing et 
al., 2011; Meyer et al., 2011). The $\mathrm{Zr}$ content of rutile crystallised in a zircon-saturated environment is strongly dependent on temperature (Zack et al., 2004b; Watson et al., 2006; Ferry and Watson, 2007; Tomkins et al., 2007), and Zr-in-rutile is used as a geothermometer, commonly coupled to the Ti-in-zircon thermometer. Uranium can be easily accommodated in the crystalline structure of rutile due to the comparable ionic radius and charge to $\mathrm{Ti}^{4+}$, hence rutile can be dated by the $\mathrm{U}-\mathrm{Pb}$ method, but it has comparatively received far less attention than zircon perhaps due to its usually lower $U$ concentration (from as low as $<0.01$ ppm to $100 \mathrm{ppm}$ ) and to the lack of rutile mineral reference materials needed for microprobe dating. However, rutile has been used for some years by the ID-TIMS (isotope dilution thermal ionisation mass spectrometry) community for high precision dating via the U-Pb system. For further reading on rutile properties and applications in the earth sciences the reader is referred to Meinhold (2010).

The radiogenic $\mathrm{Pb}$ content of rutile is a function of the time since it cooled below its closure temperature $\left(\mathrm{T}_{\mathrm{C}}\right)$ and accumulated $\mathrm{Pb}$ due to the radioactive decay of $\mathrm{U}$. When this $\mathrm{T}_{\mathrm{C}}$ is lower than the crystallisation temperature (Dodson, 1973) the measured age represents the time of cessation of $\mathrm{Pb}$ volume diffusion during cooling. $\mathrm{T}_{\mathrm{C}}$ is a function of diffusivity, cooling rate, and effective diffusion radius. Mezger et al. (1989) used ID-TIMS to date rutile grains from amphibolite to granulite facies metapelitic rocks, and compared the results to dates obtained for other minerals with reasonably well-known $\mathrm{T}_{\mathrm{C}}$ (zircon, garnet, sphene, monazite, as well as hornblende and biotite dated by the $\mathrm{K}-\mathrm{Ar}$ and ${ }^{40} \mathrm{Ar} /{ }^{39} \mathrm{Ar}$ method). This empirical calibration resulted in $\mathrm{T}_{\mathrm{C}}$ estimates for rutile of 380 and $420{ }^{\circ} \mathrm{C}$ depending on grain size of crystals (respectively 70-90 and 90-210 $\mu \mathrm{m}$ ). These estimates were later upwardsrevised to 500 and $540{ }^{\circ} \mathrm{C}$ (for rutile with diameter 140-180 and 180-420 $\mu \mathrm{m}$; Vry and Baker, 2006). Based on diffusion experiments over the range $700-1100{ }^{\circ} \mathrm{C}$ on natural and synthetic rutile with significant differences in trace element composition, Cherniak (2000) calculated mean $\mathrm{T}_{\mathrm{C}}$ of $\sim 600{ }^{\circ} \mathrm{C}$ for rutile grains of $\sim 100 \mu \mathrm{m}$ size. Observed age heterogeneity, determined by LA-ICP-MS (laser ablation inductively coupled plasma mass spectrometry), within relatively large grains (up to $280 \mu \mathrm{m}$ in size) from granulite facies Archean metapelitic rocks showing systematic core-to-rim decrease of several tens of millions of years (640 to $510^{\circ} \mathrm{C}$ ) and increase in age-gradient, lead Kooijman et al. (2010) to interpret the intragrain U$\mathrm{Pb}$ variations as cooling ages recording points in time where the system effectively closed for $\mathrm{Pb}$, and to construct closure temperature profiles $\left(\mathrm{T}_{\mathrm{C}}(\mathrm{x})\right.$, Dodson, 1986) across the grains. $\mathrm{U}-\mathrm{Pb}$ dates obtained for rutile are younger than coexisting zircon and represent the time of 
cessation of $\mathrm{Pb}$ volume diffusion during cooling below $\sim 500{ }^{\circ} \mathrm{C}$; rutile can thus be used as a thermochronometer in studies aimed at constraining the timing of metamorphism or the thermal evolution of igneous and metamorphic terranes (Schärer et al., 1986; Corfu and Muir, 1989; Mezger et al., 1989; Flowers et al., 2005; 2006; Storey et al. 2007; Kylander-Clark et al., 2008; Li et al., 2011; Blackburn et al., 2011, 2012). Growing interest is also being paid to $\mathrm{U}-\mathrm{Pb}$ chronology of detrital rutile as a provenance indicator (Allen and Campbell, 2007; Birch et al., 2007; Rösel et al., 2011; Meinhold et al., 2011; Okay et al., 2011). While U-Pb chronology of rutile by ID-TIMS is a well established technique and allows high precision ratios to be measured (e.g., Ludwig and Cooper, 1984; Schärer et al., 1986; Corfu and Andrews, 1986; Mezger et al., 1989; Davis, 1997; Cox et al., 2002; Treloar et al., 2003; Schmitz and Bowring, 2003), rutile can also be dated by microprobe (secondary ion mass spectrometry - SIMS, LA-ICP-MS) techniques (Sircombe, 1995; Clark et al., 2000; Vry and Baker, 2006; Harrison et al., 2007; Storey et al., 2007; Kooijman et al., 2010; Meinhold et al., 2011; Zack et al., 2011; Schmitt and Zack, 2012; Taylor et al., 2012).

A potential issue for $\mathrm{U}-\mathrm{Pb}$ dating of rutile, especially in young, less radiogenic samples, is the relatively large proportion of common (non radiogenic) $\mathrm{Pb}$ (i.e., which can be incorporated into the crystal structure during crystallisation or derived from contamination) resulting in low ratios of radiogenic $\mathrm{Pb}$ to common $\mathrm{Pb}$ (e.g., Treloar et al., 2003 from UHP rocks). The problem has been variably addressed, most commonly by assessing the common $\mathrm{Pb}$ composition at the time of crystallisation using multiple analyses of rutile and mineral isochrons, or by assuming a model-based composition of common $\mathrm{Pb}$ using measured ${ }^{204} \mathrm{~Pb}$ in the same mineral, or by applying a correction for the common $\mathrm{Pb}$ content following the determination of the common $\mathrm{Pb}$ composition as measured in a (U-Th poor) mineral coexisting in the same rock, the latter method not being applicable to detrital samples. Alternatively, making use of the observation that rutiles contain very low Th (hence negligible radiogenic ${ }^{208} \mathrm{~Pb}$ from ${ }^{232} \mathrm{Th}$ decay), the measured isotopic ratios can be corrected for common $\mathrm{Pb}$ by measuring ${ }^{208} \mathrm{~Pb}$ and assuming it is virtually entirely common $\mathrm{Pb}$ (Clark et al., 2000; Allen and Campbell, 2007; Kooijman et al., 2010; Zack et al., 2011). Currently, strategies are not available for handling reference material data with variable common- $\mathrm{Pb}$ to determine normalisation factors for LA U-Pb dating. In the absence of this, data must first be corrected for common- $\mathrm{Pb}$ using one of the above approaches. However, the routine application of a common $\mathrm{Pb}$ correction and the necessary uncertainty propagation, risks masking scatter in the reference material data which may or may not be relevant to the nature 
of the sample analysis. Equally, correction and propagation of the sample datapoints may mask the resolution of further age scatter. In addition to the inability of some instrumental setups to measure precisely some relevant isotopes (e.g. ${ }^{204} \mathrm{~Pb},{ }^{208} \mathrm{~Pb}$ ), the problem of determining normalisation factors from data with variable common $\mathrm{Pb}$ and the additional uncertainty contribution, makes favourable the use of a reference material without significant common- $\mathrm{Pb}$ if one could be found. In this study, $\mathrm{U}-\mathrm{Pb}$ dating by LA-MC-ICP-MS is applied to detrital rutile and two new natural rutile materials (Sugluk-4 and PCA-S207) are presented as primary and secondary reference materials to use during analysis, for which high precision ID-TIMS U-Pb and abundant LA U-Pb dates have also been determined. An approach of reference material and sample analysis is developed and presented that can be applied to the wider challenge of detrital rutile single grain $\mathrm{U}-\mathrm{Pb}$ dating for provenance studies. Our approach benefits from the use of multi-collector ICP-MS which typically exhibit better detection efficiencies than single-collector sector-field or quadrupole-ICP-MS techniques as well as simultaneous measurement of ion beams resulting in higher precisions for equivalent analysis durations (or the use of shorter acquisition times and lower ablation volumes whilst achieving equivalent precision). This allows accurate determination of the vast majority of rutiles in a sediment (> 75 and $90 \%$ on average, using a 35-40 or $50 \mu \mathrm{m}$ spot size, respectively, based on 16 modern river sand samples 6 of which are shown in this study) without requirement for concentration pre-screening which might serve to bias the population distribution. We show that our reference materials are near-concordant with a low relative common $\mathrm{Pb}$ content and a long-term reproducibility only modestly worse than long-term data for zircon reference materials. This eliminates the necessity for a common $\mathrm{Pb}$ correction to be applied to the reference data before establishing the $\mathrm{U} / \mathrm{Pb}$ normalisation value as well as the uncertainty propagation which would also be necessitated. Due to the lower $\mathrm{T}_{\mathrm{C}}$ of rutile compared to zircon, rutile has the potential to become a key tracer in sedimentary provenance, especially in combination with zircon, as together they provide a better defined isotopic fingerprint of the source region. Additionally, the availability of good quality reference materials will favour the application of $\mathrm{U}-\mathrm{Pb}$ dating of detrital rutile in provenance studies in the future.

\section{Rutile reference materials}

Two rutile samples from granulite facies metasedimentary rocks, Sugluk-4 (Sugluk-4-87 of Parrish, 1989) and PCA-S207 (PCA-S207-90-A), were chosen as candidate reference materials due to their abundance, general lack of inclusions and their age and tectonic setting. 
One of our objectives was to identify materials of sufficient quantity, quality and suitability in order to be able to distribute aliquots of both materials to other laboratories on request. The two rutile samples consist of gram-quantities that generally fall in a grain size range of 100$500 \mu \mathrm{m}$. Sugluk-4 is a granulite facies quartzite from the Ungava segment of the TransHudson orogen of Canada (Sugluk-4) and PCA-S207 is a highly strained granulite facies paragneiss ("upper deck diatexite" of Hanmer et al., 1994) from the East Lake Athabasca region (Canada). The exact geographical coordinates are indicated in Table 1 and further details on the geological and metamorphic setting of these samples (not necessarily relevant to their use as reference materials) can be found in the Supplementary data file. The garnetbearing paragneiss PCA-S207 is a leucocratic banded rock with 0.2 to $3 \mathrm{~mm}$ thick ribbons of quartz alternating to granular layers of quartz and alkali feldspar, with minor twinned plagioclase. The planar fabric wraps around 1 to $5 \mathrm{~mm}$ garnet porphyroclasts colourless in thin section. Reddish brown rutile 0.1 to $0.5 \mathrm{~mm}$ across is a relatively abundant accessory phase. Sample Sugluk-4 is an isotropic quartzite made of large (up to a few $\mathrm{cm}$ ) quartz domains with irregular contacts and minor interstitial sericitized feldspar domains with relics of crosshatched twinning. Isolated white mica flakes $(\sim 1 \mathrm{~mm})$ are present. Rutile is rarely observed in thin section. Images of PCA-S207 and Sugluk-4 rutile grains are shown in Fig.1. The grains range in size from a few tens $\mu \mathrm{m}$ to several hundreds $\mu \mathrm{m}$, are translucent and brown-red to dark-brown, with Sugluk-4 grains idioblastic to sub-idioblastic (Fig. 1a), while PCA-S207 grains are commonly xenoblastic (Fig. 1i). Colour zoning is rare. In thin section the grains are reddish brown (Figs. 1b, d, e, 1, n, o) and can show twinning (e.g. Fig. 1c). BSE imaging did not reveal zonation patterns (Figs. 1f, g, h, q, r, s).

\section{Analytical methods for reference material characterisation}

Rutile grains were isolated from the samples by mineral separation techniques making use of standard crushing, milling, dense liquid separation and Frantz magnetic separation. In characterising the rutiles, typical grains were selected, mounted in epoxy resin and polished to expose their interiors. The characterised grains are representative of rutile grains from the separates and are not specially selected.

\subsection{ID-TIMS U-Pb dating}

ID-TIMS U-Pb dates of rutile were measured at the NERC Isotope Geosciences Laboratory (NIGL), British Geological Survey, UK. Single rutile crystals or fragments were hand-picked, photographed (in transmitted light) and rinsed (in ultrapure acetone) prior to being transferred 
to $300 \mu \mathrm{l}$ Teflon FEP microcapsules and spiked with a mixed ${ }^{233} \mathrm{U}_{-}{ }^{235} \mathrm{U}_{-}{ }^{205} \mathrm{~Pb}$ tracer. Rutile was dissolved in $\sim 120 \mu \mathrm{l}$ of $29 \mathrm{M} \mathrm{HF}$ with a trace amount of $30 \% \mathrm{HNO}_{3}$ with microcapsules placed in Parr vessels at $\sim 220^{\circ} \mathrm{C}$ for $>60$ hours; total dissolution was checked by visual inspection during each dissolution batch. Solutions were dried to fluorides, and then converted to chlorides at $\sim 180{ }^{\circ} \mathrm{C}$ overnight. $\mathrm{U}$ and $\mathrm{Pb}$ for all minerals were separated using standard $\mathrm{HBr}-\mathrm{HCl}$ based anion-exchange chromatographic procedures.

Isotope ratios were measured using a Thermo-Electron Triton thermal ionisation massspectrometer (TIMS). $\mathrm{Pb}$ and $\mathrm{U}$ were loaded together on a single Re filament in a silicagel/phosphoric acid mixture (Gerstenberger and Haase, 1997). Pb was measured by peakhopping on a single SEM detector. U isotopic measurements were made in static Faraday mode. Age calculation and uncertainty estimation (including U/Th disequilibrium) was based upon the algorithms of Schmitz and Schoene (2007).

\subsection{LA-MC-ICP-MS U-Pb dating}

Laser ablation U-Pb data were collected using either a $193 \mathrm{~nm}$ or a $213 \mathrm{~nm}$ wavelength laser ablation system (UP193SS, UP193FX and UP213SS, New Wave Research) coupled to a Nu Plasma HR multiple-collector inductively coupled plasma mass spectrometer (MC-ICP-MS, $\mathrm{Nu}$ Instruments). The mass spectrometer used has a specially designed collector block to allow simultaneous detection of all masses in the range 202-207, 235 and 238. Methods followed those described in Thomas et al. (2010) with the data reduction and uncertainty propagation methodologies described in Horstwood et al. (2003). Instrument parameters used during analysis are detailed in Table A (Supplementary data file). Either a low-volume (volume $\sim 3 \mathrm{~cm}^{3}$, Horstwood et al., 2003) or a two-volume (Large Format Cell of New Wave Research) ablation cell were used for sample analysis. The laser sampling protocol employed a 35,40 or $50 \mu \mathrm{m}$ static spot - depending on crystal size - and a fluence of $2-3 \mathrm{~J} / \mathrm{cm}^{2}$ (independently calibrated). Analysis was performed using the Time Resolved Analysis (TRA) mode of the Nu Plasma software with signals integrated excluding the first 3-5 s of data and the data normalised and uncertainty propagated offline using an in-house Excel spreadsheet. After an initial $30 \mathrm{~s}$ instrument baseline measurement and $30 \mathrm{~s}$ gas blank, individual analysis ablation times were $40 \mathrm{~s}$ for a run of 10-15 ablations. Average pit depth estimates of $\sim 20 \mu \mathrm{m}$ were confirmed by independent SEM measurements on a few grains (Fig. 2). Ion beams for mass $204(\mathrm{~Pb}$ and $\mathrm{Hg}),{ }^{206} \mathrm{~Pb}$ and ${ }^{207} \mathrm{~Pb}$ were collected on ETP discrete dynode electron multipliers with all other peaks collected on analogue (Faraday) detectors. The simultaneous measurement of the ${ }^{202} \mathrm{Hg}$ signal allows correction for the isobaric interference of ${ }^{204} \mathrm{Hg}$ on 
${ }^{204} \mathrm{~Pb}$ during the ablation. Detection of very small amounts of ${ }^{204} \mathrm{~Pb}$ is however currently hampered by the quantity of $\mathrm{Hg}$ in the gas blank, leading to a relatively high on-peak subtracted noise level on ${ }^{204} \mathrm{~Pb}$, masking the low ${ }^{204} \mathrm{~Pb}$ signals typical of many rutile ablations and ultimately leading to poor precision on small common $\mathrm{Pb}$ corrections. A desolvating nebuliser (DSN-100, Nu Instruments) was used to simultaneously aspirate a solution containing $\mathrm{Tl}$ (with isotopes 203 and 205) and ${ }^{235} \mathrm{U}$ in order to correct for mass spectrometerrelated mass bias $\left(\mathrm{Pb} / \mathrm{Pb}\right.$ ratios using ${ }^{205} \mathrm{Tl} /{ }^{203} \mathrm{Tl}, \mathrm{Pb} / \mathrm{U}$ ratios using $\left.{ }^{205} \mathrm{Tl} /{ }^{235} \mathrm{U}\right)$ at the time of analysis. Elemental fractionation from other sources (laser- and plasma-induced) was corrected by comparison of laser ablation data for a primary reference material to ID-TIMS data. In line with best practice in laser ablation analysis, at least one secondary reference material is required to validate the results and assess the quality of the $\mathrm{U}-\mathrm{Pb}$ data, hence both reference rutiles were analysed in each session, one to provide validation for the corrections determined from the other. Uncertainties for the ${ }^{207} \mathrm{~Pb} /{ }^{206} \mathrm{~Pb}$ ratios were propagated using quadratic addition to combine the measurement uncertainty with a reproducibility component modelled to reflect increasing uncertainty with decreasing signal size (see Horstwood et al., 2003 for details). A minimum uncertainty of $0.5 \%(2 \sigma)$ was assigned to the ${ }^{207} \mathrm{~Pb} /{ }^{206} \mathrm{~Pb}$ ratio by default for ablations with high ${ }^{207} \mathrm{~Pb}$ ion beams, to reflect the confidence in the ability of the multi-ion counting (MIC) set-up to accurately reproduce any one value. ${ }^{206} \mathrm{~Pb} /{ }^{238} \mathrm{U}$ uncertainties were propagated in a similar way utilising the measurement uncertainty and the reproducibility of the ablation reference material used. During each analytical session both zircon and rutile reference materials were measured between each group of unknowns to determine the degree of elemental fractionation, to monitor the effect of matrix (zircon vs. rutile) on the degree of elemental fractionation, and to assess instrumental accuracy. GJ-1 zircon reference material $\left({ }^{206} \mathrm{~Pb} /{ }^{238} \mathrm{U}\right.$ age $=600.4 \pm 0.6 \mathrm{Ma}$, Jackson et al., 2004; 602.3 $\pm 1 \mathrm{Ma}$ NIGL TIMS data unpublished) was used as the primary zircon reference material with Mud Tank (732 \pm 5 Ma, Black and Gulson, 1978) and 91500 (1062.4 \pm 0.4 Ma, Wiedenbeck et al., $1995)$ or Plešovice (337.1 \pm 0.4 Ma, Sláma et al., 2008) as secondary zircon reference materials. Sugluk-4 and PCA-S207 were analysed as primary and secondary rutile reference materials respectively. The weighted means of the ${ }^{207} \mathrm{~Pb} /{ }^{206} \mathrm{~Pb}$ and ${ }^{206} \mathrm{~Pb} /{ }^{238} \mathrm{U}$ Sugluk-4 ratios obtained by ID-TIMS (without correction for common $\mathrm{Pb}$ ) were used as the reference values to determine the normalisation factors relative to the average ${ }^{207} \mathrm{~Pb} /{ }^{206} \mathrm{~Pb}$ and ${ }^{206} \mathrm{~Pb} /{ }^{238} \mathrm{U}$ (after mass-bias correction (mbc) using the Tl-U solution) obtained over the course of each LAMC-ICP-MS analytical session. These factors were used to normalise the data for the 
validation (PCA-S207) and sample analyses. All plots and age calculations have been made using the Isoplot v. 4.14 (Ludwig, 2003) add-in for Microsoft Excel.

\subsection{Determination of trace element composition by LA-ICP-MS}

Laser ablation ICP-MS was used to determine the trace element content of rutile grains from Sugluk-4 and PCA-S207. Element concentrations were measured at the University of Portsmouth using an Agilent 7500cs quadrupole ICP-MS coupled to a New Wave UP213 laser ablation sampling system. Helium was used as a carrier gas and mixed with Ar via a connector prior to the torch. Spots were located as close as possible to the spots used for LA $\mathrm{U}-\mathrm{Pb}$ dating. Data were collected using a $60 \mathrm{~s}$ acquisition and backgrounds were measured as a gas blank for the first $30 \mathrm{~s}$. The spot size was $40 \mu \mathrm{m}$ with a repetition rate of $10 \mathrm{~Hz}$ and laser fluence was maintained at $\sim 4 \mathrm{~J} / \mathrm{cm}^{2}$. NIST SRM 610 glass (Pearce et al., 1997) was used as the reference material for concentration determination, to correct for elemental fractionation and mass bias and was measured at the beginning and end of data acquisition and between each group of 14 unknowns. Internal standardisation was done stoichiometrically by assuming $\mathrm{TiO}_{2}=98 \mathrm{wt} \%$ in rutile. Oxide formation was kept below $0.1 \%$ by monitoring $\mathrm{Th} / \mathrm{ThO}^{+}$. Rutile R10 was monitored within each run and checked against the published values of Luvizotto et al. (2009). The data were reduced offline using Lamtrace (Simon Jackson, Geological Survey of Canada). All of the elements analyzed were reproduced to within 4 and $9 \%(1 \sigma)$, with the exception of $\mathrm{Al}$ and $\mathrm{W}(20 \%)$, on the basis of long-term reproducibility.

\section{Reference materials results}

\subsection{Mineral chemistry}

Selected typical Sugluk-4 and PCA-S207 rutile grains were analysed for chemical composition and intragrain variability, as tested by ablating different areas of individual grains (e.g., Figs. 1h and 1s; Table 1). A selection of elements in the mass range 27-238 was measured by LA-ICP-MS, with many being below the detection limit of the technique (e.g., $\mathrm{Mn}, \mathrm{Rb}, \mathrm{Sr}, \mathrm{Y}$, the Rare Earth Elements; these are not included in Table 1). The most abundant trace elements (in the range of hundreds to a few thousand ppm) are $\mathrm{Zr}, \mathrm{Cr}, \mathrm{Nb}$ and V. The concentrations of the trivalent elements Sc and Al differ in Sugluk-4 and PCA-S207 rutiles with PCA-S207 enriched in Al and Sugluk-4 in Sc (Fig. 3a). The HFSE (High Field Strength Elements, such as $\mathrm{Zr}, \mathrm{Nb}, \mathrm{Mo}, \mathrm{Sn}, \mathrm{Hf}$, Ta, W) of which rutile is a main carrier mineral phase (e.g., Rudnick et al., 2000) occur in variable amounts in the analysed grains. $\mathrm{Zr}$ and Hf show broad positive correlations, and form two distinct trends for Sugluk-4 (lower 
$\mathrm{Zr} / \mathrm{Hf}$ ) and PCA-S207 (higher Zr/Hf, Table 1 and Fig. 3b). Nb occurs with concentrations up to $2000 \mathrm{ppm}$ and is more homogeneously distributed in Sugluk-4 than in PCA-S207 (Fig.

3c). The $\mathrm{Nb} / \mathrm{Ta}$ ratio of PCA-S207 and Sugluk-4 varies in the range 9-62 and 15-78, respectively (Table 1 and Fig. 3c). Cr and V are broadly positively correlated (Fig. 3d). Sugluk-4 is also characterized by less variable $\mathrm{Cr} / \mathrm{Nb}$ ratios $(0.5-1)$ than PCA-S207 (0.5-3, Table 1 and Fig. 3e). The measured $U$ concentration is in the range $12-40$ and $24-98$ ppm in PCA-S207 and in Sugluk-4 respectively (Fig. 3f), while Th occurs below an average detection limit of $\sim 0.001 \mathrm{ppm}$. For a few grains for which $\mathrm{U}-\mathrm{Pb}$ isotopes had been measured by LAMC-ICP-MS on a corresponding spot, the $\mathrm{Pb}$ concentration has been calculated using the measured U concentration and is 5 to 9 ppm (PCA-S207) and 8 to 30 ppm (Sugluk-4), (Table 1). The higher $\mathrm{U}$ and $\mathrm{Pb}$ content in Sugluk-4 is also confirmed by the $\mathrm{U}$ and $\mathrm{Pb}$ content estimated on the basis of GJ1 zircon analysed in the same LA U-Pb session, with an average of $7(\mathrm{~Pb})$ and $17(\mathrm{U})$ ppm for PCA-S207, $11(\mathrm{~Pb})$ and $30(\mathrm{U})$ ppb for Sugluk-4 (Table D, Supplementary data file). Overall, Sugluk-4 is a more chemically homogeneous material than PCA-S207. In some grains and for some elements (e.g. Nb, Ta, Zr, Hf) some intragrain chemical variability can be observed (e.g. Figs. $3 g$ to 31 ). Temperatures calculated applying the Zr-in-rutile thermometer (based on the calibration of Tomkins et al., 2007) are in the range of $700-760{ }^{\circ} \mathrm{C}$ (assuming a $\mathrm{P}$ of $6 \mathrm{kbar}$ ) and $710-780{ }^{\circ} \mathrm{C}(10 \mathrm{kbar})$ for Sugluk-4 and $680-770{ }^{\circ} \mathrm{C}$ (6 kbar) and $700-790{ }^{\circ} \mathrm{C}(10 \mathrm{kbar})$ for PCA-S207, consistent with granulite facies conditions of the two rutiles (Table 2).

\subsection{U-Pb isotopic results}

\subsubsection{ID-TIMS}

Rutile ID-TIMS U-Pb data for ten Sugluk-4 and four PCA-S207 individual grains are presented in Table 3, along with analyses of four fragments of the R10 monocrystalline rutile (Luvizotto et al., 2009). The results, both before and after correction for common $\mathrm{Pb}$, are plotted on Wetherill concordia diagrams (Fig. 4). The data for Sugluk-4 (Table 3 and Fig. 4a) detail the presence of small amounts of common $\mathrm{Pb}(0.2-1.6 \%$ for 8 of 10 analyses). After common $\mathrm{Pb}$ correction (using the Stacey-Kramers (1975) model for terrestrial Pb evolution at $1.7 \mathrm{Ga}$ ), the data form a co-linear array regressing to near-zero age with an upper intercept age of $1723.0 \pm 6.8 \mathrm{Ma}(2 \sigma$, including decay constant uncertainties, MSWD $=11$, excluding one point). However the exact interpretation of rutile ages is complicated and this will be discussed later. Importantly, the average ${ }^{206} \mathrm{~Pb} /{ }^{238} \mathrm{U}$ and ${ }^{207} \mathrm{~Pb} /{ }^{206} \mathrm{~Pb}$ ratios differ by $<1 \%$ for 8 of the 10 grains whether or not they are corrected for common $\mathrm{Pb}$ (Fig. 4a). This level of 
potential inaccuracy is currently appropriate for LA-ICP-MS dating for a mineral with limited available alternative reference materials. On the scale of current laser ablation uncertainties $(2 \%, 2 \sigma)$ therefore, it makes little difference whether the ID-TIMS common Pb corrected or non-corrected ${ }^{206} \mathrm{~Pb} /{ }^{238} \mathrm{U}$ and ${ }^{207} \mathrm{~Pb} /{ }^{206} \mathrm{~Pb}$ ratios of Sugluk-4 are used as the primary reference values for normalising the laser ablation data. For materials with a higher relative common $\mathrm{Pb}$ content (e.g. R10, see later) this difference is important and requires like-for-like data normalisation if used as a primary reference material. With this in mind and the knowledge that age variations related to cooling are present and normal in many rutiles, the Sugluk-4 (radiogenic plus common $\mathrm{Pb}$ ) ${ }^{206} \mathrm{~Pb} /{ }^{238} \mathrm{U}$ and ${ }^{207} \mathrm{~Pb} /{ }^{206} \mathrm{~Pb}$ ratios for normalisation of the LA data were defined as $0.3060 \pm 2 \%$ and $0.1070 \pm 1.4 \%$ (2RSD), respectively

Four PCA-S207 rutile grains show higher relative common Pb contents of 2.9-45\% compared to Sugluk-4, the very high relative common $\mathrm{Pb}$ content of one grain possibly due to an inclusion of another mineral. The four points do not form a co-linear common $\mathrm{Pb}$ array and after common $\mathrm{Pb}$ correction are not equivalent (Figs. $4 \mathrm{~b}$ and $4 \mathrm{c}$ ). The average PCA-S207 ${ }^{206} \mathrm{~Pb} /{ }^{238} \mathrm{U}$ and ${ }^{207} \mathrm{~Pb} /{ }^{206} \mathrm{~Pb}$ ratios for the common $\mathrm{Pb}$ corrected data are $0.3303 \pm 1.8 \%$ and $0.1141 \pm 0.5 \%(2 \mathrm{RSD})$.

Four fragments of the 1090 Ma R10 rutile (Luvizotto et al., 2009) analysed by ID-TIMS contained $0.24-1.6 \%$ common $\mathrm{Pb}$ and were concordant after correction, but only 3 of the 4 analyses overlap at the $2 \sigma$ level; these data overlap with the bottom end of the data cluster published by Luvizotto et al (2009), (Fig. 4d). R10 was introduced and characterised by Luvizotto et al. (2009) and used as reference materials for U-Pb dating by Zack et al. (2011), therefore it is important to undertake some intercomparison of our proposed reference materials with that. Since we are not applying an online common $\mathrm{Pb}$ correction during the analysis, data values prior to common $\mathrm{Pb}$ correction need to be determined in order to use $\mathrm{R} 10$ as the main reference material. This also requires the reference material to have homogenous radiogenic $\mathrm{Pb}$ to common $\mathrm{Pb}$ ratios throughout. Using the published radiogenic ratios of fourteen R10 fragments (Table 4 of Luvizotto et al., 2009) we have back-calculated the ${ }^{207} \mathrm{~Pb} /{ }^{206} \mathrm{~Pb}$ and ${ }^{206} \mathrm{~Pb} /{ }^{238} \mathrm{U}$ ratios prior to common $\mathrm{Pb}$ correction by adding a common $\mathrm{Pb}$ component (quantified by the ${ }^{206} \mathrm{~Pb} /{ }^{204} \mathrm{~Pb}$ of their Table 4) with a composition calculated at 1090 Ma using the Stacey-Kramers (1975) model for terrestrial Pb evolution (Table B, Supplementary data file). These are plotted on a Wetherill concordia diagram along with the R10 fragments measured in this study (Fig. 4e). With ${ }^{206} \mathrm{~Pb} /{ }^{204} \mathrm{~Pb}$ ratios of 330 to 4000 with most being less than 1000, R10 is clearly not appropriate for our purposes as a reference 
material prior to common $\mathrm{Pb}$ correction. In addition, based on Fig. 4e, it is possible that the two sets of data do not lie on the same regression trend indicating that there are variable age and/or common $\mathrm{Pb}$ components within $\mathrm{R} 10$. For our purposes therefore, and for others who do not or prefer not to measure ${ }^{204} \mathrm{~Pb}$ and/or ${ }^{208} \mathrm{~Pb}, \mathrm{R} 10$ can not serve as a primary reference material.

\subsubsection{LA-MC-ICP-MS}

Rutile LA-MC-ICP-MS U-Pb data were acquired over a period of ca. two years (29 analytical sessions for a total of $\sim 2500$ single ablations, including 1800 ablations of grains from 26 unknown detrital samples; six of these detrital samples are presented in this paper -section 5to show our approach on real samples). Over the $\sim 2$ year period of our LA U-Pb rutile measurements and during the same analytical sessions we also measured three commonlyused zircon reference materials (Table C, Supplementary data file). The long-term reproducibility (2RSD) of the ${ }^{207} \mathrm{~Pb} /{ }^{206} \mathrm{~Pb}$ and ${ }^{206} \mathrm{~Pb} /{ }^{238} \mathrm{U}$ ratios for the secondary zircon reference materials normalised to GJ1 (Figs. 5b to 5c) over the same period was 2.0 and $3.0 \%$ for Mud Tank ( $\mathrm{n}=157), 1.5$ and 3.3\% for Plešovice $(\mathrm{n}=25), 1.8$ and 2.6\% for $91500(\mathrm{n}=$ 106). These data demonstrate that instrument performance during this period was good. Sugluk-4 rutile LA U-Pb data (486 spot ablations on 72 grains; Table D, Supplementary data file) are plotted on a Tera-Wasserburg diagram along with the ID-TIMS analyses of individual grains (Fig. 5a, all data not corrected for common $\mathrm{Pb}$ ). The Sugluk-4 ${ }^{207} \mathrm{~Pb} /{ }^{206} \mathrm{~Pb}$ ratios not corrected for common $\mathrm{Pb}$ exhibit an asymmetric probability density distribution with a positive skew (Fig. 6a). The same data are shown as linearised probability plot (Fig. 7a) after the exclusion of datapoints with ${ }^{207} \mathrm{~Pb} /{ }^{206} \mathrm{~Pb}>0.11$ (14 out of 486 , i.e. $3 \%$ ), under the assumption that these higher ratios reflect the occurrence of common $\mathrm{Pb}$ despite this being below a level detectable with our analytical set-up. On the linearised probability plot the main set of data disperse along a linear trend with a slope of $\sim 1$ as a normal distribution would do. The ${ }^{206} \mathrm{~Pb} /{ }^{238} \mathrm{U}$ distribution (of the 486 datapoints) also exhibits a skew, as shown by the probability density plot in Fig. 6b. Excluding the same 14 data points with higher relative common $\mathrm{Pb}$ as excluded in Fig. 7a, the residual scatter in ${ }^{206} \mathrm{~Pb} /{ }^{238} \mathrm{U}$ ratio shown by the linearised density plot (Fig. 7b) but not evident in ${ }^{207} \mathrm{~Pb} /{ }^{206} \mathrm{~Pb}$ space (Fig. 7a), is caused by 13 analyses of the remaining 472 with anomalously high ${ }^{206} \mathrm{~Pb} /{ }^{238} \mathrm{U}$. The origin of this is currently unknown although is likely to be real variation arising from the protracted cooling history of the sample. $\mathrm{The}{ }^{207} \mathrm{~Pb} /{ }^{206} \mathrm{~Pb}$ average of the 472 datapoints illustrated as a linearised probability plot (Fig. 7a) is $0.1069 \pm 0.0021(2.0 \%, 2 \mathrm{SD})$. The ${ }^{206} \mathrm{~Pb} /{ }^{238} \mathrm{U}$ average of 459 
datapoints illustrated as a linearised probability plot (Fig. 7c) is $0.306 \pm 0.011(3.6 \%, 2 \mathrm{SD})$. This long-term reproducibility of the ${ }^{207} \mathrm{~Pb} /{ }^{206} \mathrm{~Pb}$ and ${ }^{206} \mathrm{~Pb} /{ }^{238} \mathrm{U}$ ratios for Sugluk-4 is equal to or slightly worse than that of zircon reference materials analysed over the same period (1.5 to $2.0 \%$ and 2.6 to $3.3 \%$ respectively). However, the same individual rutile grain ablated over different analytical sessions or different grains analysed within the same session are more reproducible (e.g. note the ${ }^{206} \mathrm{~Pb} /{ }^{238} \mathrm{U}$ reproducibility dropping to $<3 \%$ in Figs. $7 \mathrm{~d}$ and $7 \mathrm{e}$ ) suggesting that inter-grain variation combined with session-to-session scatter are the controlling factors on data homogeneity.

Allowing for natural variations induced by protracted cooling and assuming no $\mathrm{Pb}$ loss in rutile our best estimate for the age of Sugluk-4 is $1719 \pm 14 \mathrm{Ma}$ (the average and 2SD of 8 out of ten ID-TIMS data, see section 4.2.1). It is important to note, however, that slow cooling and related diffusion will inevitably induce some intragrain and intergrain age variation (e.g. Baldwin et al., 2004; Flowers et al., 2006; Kooijman et al., 2010) and that in some grains this would be measurable leading to a preferred age different to the one stated. With a sufficiently high sample quantity, this may appear in a dataset as a slight heterogeneity, consistent with what has been observed. In light of this natural variation, the ${ }^{207} \mathrm{~Pb} /{ }^{206} \mathrm{~Pb}$ and ${ }^{206} \mathrm{~Pb} /{ }^{238} \mathrm{U}$ ratios used to represent Sugluk 4 are therefore an average based on the ID-TIMS data with an uncertainty assigned $(2.0 \%$ and $3.6 \%, 2 \mathrm{SD})$ which allows for this variation and provides a limiting uncertainty in the interpretation of the data. Data reported by Zack et al. (2011) for $\mathrm{R} 10$ cite within run reproducibility at $3.5 \%$ (2SD). Therefore, using Sugluk-4 as a primary reference material results in limiting uncertainties equivalent to R10.

PCA-S207 LA U-Pb data (normalised to Sugluk-4 and not corrected for common Pb, 412 spot ablations on 85 grains; Table D, Supplementary data file) are shown in Fig. 8a as a TeraWasserburg diagram, along with the ID-TIMS analyses of individual grains. The same LA U$\mathrm{Pb}$ data are shown as probability plots (Figs. $8 \mathrm{~b}$ and $8 \mathrm{c}$ ) and as linearised probability plots after the exclusion of datapoints with ${ }^{207} \mathrm{~Pb} /{ }^{206} \mathrm{~Pb}>0.122$ (14 out of 400 , i.e. $4 \%$ ), under the assumption that these higher ratios are due to common $\mathrm{Pb}$ at the limits of detection for our analytical set-up. Similarly to Sugluk-4, there is a residual scatter that can be explained in terms of either $\mathrm{Pb}$ loss or more likely the effects of the protracted cooling that may have caused some real intergrain variation. This is reflected in the data populations in Figs. $8 \mathrm{~b}$ and $8 \mathrm{c}$ being clearly non-normally distributed. Here the cooling history of PCA-S207 might be responsible for the larger variability of the ${ }^{207} \mathrm{~Pb} /{ }^{206} \mathrm{~Pb}$ and ${ }^{206} \mathrm{~Pb} /{ }^{238} \mathrm{U}$ ratios compared to Sugluk-4. Nonetheless, the intragrain or short term (daily) variability of PCA-S207 is usually 
below $4.0 \%(2 \sigma)$ for both ratios. Our best estimate for the age of PCA-S207 rutile is $1865.0 \pm$ 7.5 Ma (weighted average of ${ }^{207} \mathrm{~Pb} /{ }^{206} \mathrm{~Pb}$ ID-TIMS dates, based on four concordant to nearly concordant grains ranging from 1862.2 \pm 2.8 to $1872.2 \pm 2.6 .95 \%$ conf., MSWD $=13$ ); this is in good agreement with ${ }^{207} \mathrm{~Pb} /{ }^{206} \mathrm{~Pb}$ rutile dates in the range $1850.8 \pm 1.4$ to $1881.6 \pm 2.4 \mathrm{Ma}$ and $1874.0 \pm 1.0$ to $1892.9 \pm 5.8 \mathrm{Ma}$ from an eclogite and the Axis mafic granulite from the southern domain of the East Atabasca Mylonite triangle (ID-TIMS data, 6 grains each; Baldwin et al., 2004; Flowers et al., 2006) from where PCA-S207 has been sampled (see Geological and thermochronological setting, Supplementary data file). Interestingly Baldwin et al. (2004) noticed an age-correlation with grain size and interpreted it as differential closure to diffusion, and Flowers et al. (2006) argued for intracrystal variation in age that may reflect diffusional gradients developed during cooling. Our conclusions are therefore similar using the two different methods (ID-TIMS and LA-MC-ICP-MS).

In order to undertake some intercomparison of our proposed reference materials with R10 and R19 (Luvizotto et al., 2009; Zack et al., 2011), fragments of these two rutiles were ablated along with Sugluk 4 and PCA-S207 during some of the same analytical sessions. Due to the large variability in common $\mathrm{Pb}$ content in R10 highlighted in the Luvizotto et al (2009) IDTIMS data (> 50\% variability in ${ }^{207} \mathrm{~Pb} /{ }^{206} \mathrm{~Pb}$ ratio), each individual fragment of $\mathrm{R} 10$ requires knowledge of its isotopic composition and homogeneity to be used as a primary reference material. In the absence of an on-line common $\mathrm{Pb}$ correction being applied to data, a homogeneous or common $\mathrm{Pb}$-free material is required as a primary reference. Some of the data of R10 in Luvizotto et al (2009) exhibits relatively low common Pb (Table 4 of Luvizotto et al., 2009). The $\mathrm{R} 10$ data from this study demonstrate a lower relative common $\mathrm{Pb}$ content of the data than have been published so far. Using an average of these (filled ellipses of Figs. 4d and 4e) for normalisation of R19 and PCA-S207 ablated as unknown materials (Fig. 9a and 9c) concordant data are achieved (excluding two R19 discordant datapoints with higher relative common $\mathrm{Pb}$ content). The weighted average ${ }^{206} \mathrm{~Pb} /{ }^{238} \mathrm{U}$ date for $\mathrm{R} 19$ is $472.6 \pm 6.5$ (9 datapoints concordant and equivalent within uncertainty, Fig. 9a), while the published weighted average of four TIMS ${ }^{206} \mathrm{~Pb} /{ }^{238} \mathrm{U}$ dates for R19 is $489.5 \pm 0.9$ Ma (Zack et al., 2011). Using Sugluk-4 as the primary reference material, the same level of concordance results for $\mathrm{R} 19$ datapoints, and the weighted average ${ }^{206} \mathrm{~Pb} /{ }^{238} \mathrm{U}$ date is $470.1 \pm 4.9 \mathrm{Ma}$ (Fig. 9b) within uncertainty of that for the R10 normalised data. Similar results are obtained for PCA-S207, with a weighted average ${ }^{207} \mathrm{~Pb} /{ }^{206} \mathrm{~Pb}$ date of $1884.0 \pm 16.0 \mathrm{Ma}$ (Fig. 9c, normalised to R10, NIGL ID-TIMS data) and $1875 \pm 12.0 \mathrm{Ma}$ (Fig. 9d, normalised to Sugluk-4). If R10 is 
normalised to Sugluk-4 (Fig. 9e), the datapoints appear non-equivalent and most are discordant on a Tera-Wasserburg diagram, with a reproducibility of the ${ }^{207} \mathrm{~Pb} /{ }^{206} \mathrm{~Pb}$ and ${ }^{206} \mathrm{~Pb} /{ }^{238} \mathrm{U}$ ratios (mass bias corrected only) of 3.9 and $4.1 \%(2 \sigma)$ versus 2.7 and $2.9 \%$ for Sugluk-4 during the same session, reflecting the presence and variability of common $\mathrm{Pb}$ in R10. Finally, the four Sugluk-4 grains analysed over the same session are shown in Fig. 10 normalised to R10 (using the average of NIGL ID-TIMS data from this study). All datapoints with the exception of one (that belongs to the positive tail of datapoints high in relative common $\mathrm{Pb}$ content in Fig. 6a) are concordant within their analytical uncertainty, and for all the individual grains the weighted average of the ${ }^{207} \mathrm{~Pb} /{ }^{206} \mathrm{~Pb}$ dates overlaps within uncertainty with the ${ }^{207} \mathrm{~Pb} /{ }^{206} \mathrm{~Pb}$ ID-TIMS date obtained for the same grain as shown in Fig. 10, although the laser ablation date is systematically older by $0.5-1.3 \%$. This reflects both: i) the natural variation shown by the R10 ID-TIMS data (Luvizotto et al., 2009 and this study) and the difficulty in assigning absolute ratios to such a naturally heterogeneous material to be used as the reference for normalisation; and ii) any intragrain variation of Sugluk 4 (N.B. ID-TIMS values in Fig. 10 on the same grains as the laser ablation data).

Overall, these results show that: (1) Sugluk-4 is a rutile characterized by nearly concordant ID-TIMS and concordant (within uncertainty) LA U-Pb analyses, with long-term reproducibility on the order of $2-4 \%, \sim 1 \%$ more than natural zircon materials routinely used for U-Pb dating; (2) the intra- and inter-grain scatter in the isotopic ratios of Sugluk-4 are interpreted to reflect real geological rather than analytical phenomena and are most likely caused by cooling-related diffusion compatible with the slow cooling of many natural rutiles from granulite terrains; (3) PCA-S207 is characterized by a larger variability than Sugluk-4, usually within 4\% for individual grains; (4) R10 has a large degree of intergrain heterogeneity with respect to common $\mathrm{Pb}$ and each portion needs to be characterised for homogeneity if a common $\mathrm{Pb}$ correction is not to be applied to the data; (5) we recognise some real variation between and within grains likely pertaining to cooling history of many rutiles as recognised by others (e.g. Baldwin et al. 2004; Flowers et al. 2006; Kooijman et al. 2010).

Finally and most importantly for the implications to routine use as reference material, the observed total variation in ${ }^{207} \mathrm{~Pb} /{ }^{206} \mathrm{~Pb}$ and ${ }^{206} \mathrm{~Pb} /{ }^{238} \mathrm{U}$ ratios (not corrected for common $\mathrm{Pb}$ ) for $>97 \%$ of all Sugluk- 4 grains falls within the $\pm 2 \%$ and $\pm 4 \%$ range (at the $2 \sigma$ level) generally attainable using microprobe methodologies, and it is only slightly worse for PCA-S207. Sugluk-4 and PCA-S207 therefore appear to be suitable primary and secondary reference materials for $\mathrm{U}-\mathrm{Pb}$ dating of rutile by LA-ICP-MS without the requirement for correction of 
common $\mathrm{Pb}$. This makes these two materials similar to zircon reference materials in their ease of use and applicability and eliminates the need for an on-line common $\mathrm{Pb}$ correction in measuring the primary reference material which inflates the measurement uncertainties, potentially introduces systematic errors if wrong assumptions are made regarding the common $\mathrm{Pb}$ composition and further masks real variations in the data.

\section{Detrital rutile geochronology applied to sedimentary provenance}

In this section we present $\mathrm{U}-\mathrm{Pb}$ data measured on detrital rutile from modern rivers draining portions of the Canadian Cordillera (British Columbia, Canada) and the Himalayas (Bhutan), in order to illustrate the applicability of detrital rutile dating and to demonstrate that young rutile can be dated successfully by LA-MC-ICP-MS. Schematic geological maps of these areas with location of sand samples are shown in Fig. 11, and the exact geographical coordinates of the samples are indicated in Table D of the Supplementary data file.

\subsection{Detrital rutile samples from the Canadian Cordillera and Bhutan Himalayas}

Two detrital samples are from modern rivers draining the southern Omineca belt of the Canadian Cordillera (Parrish 1995), a large area of high-grade metamorphic rocks of the core of the orogen. The belt is dissected into blocks by Eocene crustal-scale faults juxtaposing footwall rocks of high metamorphic grade against hanging wall rocks that were much cooler in the Eocene (Parrish et al., 1988; Parrish 1995, and references therein). Sample BC-04g66 is from the Columbia River in the vicinity of Revelstoke (Fig. 11a). The Columbia River in this region flows southward along the Columbia fault that bounds the Monashee Complex to the west. The latter consists of Early Proterozoic crystalline basement composed of othogneisses and paragneisses and an unconformably overlying cover sequence, all significantly metamorphosed and deformed in latest Cretaceous-Paleogene time (Parrish 1995), with some variation in age as a function of structural level. $\mathrm{U}-\mathrm{Pb}$ isotopic data from xenotime and monazite representing peak metamorphic conditions young from 64 Ma to 49 Ma with increasing structural depth within the complex (Crowley and Parrish, 1999). Anatexis of the Proterozoic basement as a result of regional prograde metamorphism is constrained by $\mathrm{U}-\mathrm{Pb}$ dates from migmatitic leucosomes at 62 and 56-54 Ma (zircon) and $57 \mathrm{Ma}$ (titanite), (Hinchey et al., 2006; Gervais and Brown, 2011). Sample BC-04g67 is from the Eagle River, $40 \mathrm{~km}$ farther west of the first sample (Fig. 11a). The Eagle River flows westward and its sediments are derived almost entirely from the erosion of the Monashee complex. Rutile U-Pb ages, reflecting cooling below $\sim 500^{\circ} \mathrm{C}$, are thus expected to be in the age range of $\sim 50-55$ 
Ma for detritus eroded from the Monashee complex, the primary source of rutile of these two rivers.

Four detrital rutile samples are from modern rivers draining an eastern portion of the Himalayas in Bhutan (Fig. 11b). The Himalayan orogen formed as the results of the collision between India and Asia that started at $~ 50 \mathrm{Ma}$ and is still ongoing (Hodges, 2000; Najman et al., 2010 and references therein). The Himalayan tectonostratigraphic units exposed in Bhutan are separated by crustal scale southward-propagating thrust faults and from north to south are: the Tethyan sedimentary sequence (TH), a Palaeozoic-Mesozoic sedimentary succession deposited on the northern passive margin of India; the Proterozoic to early Paleozoic metasedimentary rocks and orthogneisses of the Greater Himalaya $(\mathrm{GH})$, highly metamorphosed during the Tertiary with peak metamorphism being 25-17 Ma, accompanied by crustal melting and emplacement of leucogranites between 23 and $12 \mathrm{Ma}$; the Lesser Himalaya (LH), a thick succession of non metamorphic or low-grade Precambrian to Palaeozoic clastic and carbonate rocks deposited upon the northern Indian margin; the Tertiary foreland basin sediments of the Siwalik Group. Within the GH of Bhutan, klippen associated with the South Tibetan Detachment expose sedimentary rocks of greenschist facies and lower metamorphic grade (Late Proterozic Chekha Formation). For further reading on the geology of Bhutan in order to set these samples into context the reader is referred to Gansser (1983), Grujic et al. (2002), Hollister and Grujic (2006), and McQuarrie et al. (2008).

Bhutan is drained by an hydrographic system broadly N-S oriented, that cuts across the main Himalayan geological units and their tectonic boundaries and eventually empties into the Brahmaputra River in the state of Assam in India. Sample BH0108 and LB09-03 are two modern river sands from the Mo Chu and the Puna Tsang Chu (Fig. 11b). The Mo (mother) Chu (river) originates in Tibet and after joining the Pho (father) Chu by Punakha becomes the Puna Tsang Chu. The sand sample LB09-01 is from the more eastern Mangdi Chu that flows in central Bhutan, while sand LB09-02 was sampled from the Mau Khola river south of the Main Central Thrust and close to the border with India (Fig. 11b). All of these samples drain variable amounts of rock of high metamorphic grade, with some containing lesser metamorphosed metasedimentary lithologies. Detrital rutile is likely to have been derived mainly from the high grade metamorphic sources which have a predominant Tertiary Himalayan metamorphic signature.

\subsection{Detrital rutile $U-P b$ data}


LA U-Pb data of detrital rutile samples (Table D, Supplementary data file) are shown in Figs. 12 and 13 as Wetherill concordia diagrams and ${ }^{206} \mathrm{~Pb} /{ }^{238} \mathrm{U}$ age probability density plots. The number of ablation spots for each sample plotted on the concordia diagrams varies from 18 to 48 as indicated, and measurement protocols were identical between samples and reference materials (Sugluk-4 and PCA-S207). For all samples, an originally larger number of grains was analysed, but some of the grains failed to produce a signal strong enough to be measured (due to low $\mathrm{Pb}$ and/or uranium content), especially when a smaller spot size was used (i.e., 5$10 \%$ of grains failed when a $50 \mu \mathrm{m}$ spot size was used and up to $30 \%$ using a 35 or $40 \mu \mathrm{m}$ spot size on fine-grained 10-15 Ma old rutile). Measured intensity of the radiogenic ${ }^{207} \mathrm{~Pb}$ was low in many grains due to young age and/or low U content (Table D, Supplementary data file). These realities are reflected in Concordia diagrams by larger uncertainty ellipses and in part by arrays of data (see below).

At times two spots were ablated from the same grain to test potential age zoning and reproducibility. These always resulted in two dates overlapping within uncertainty, of which only the one determined with the lower uncertainty was eventually included in the probability plot. Typically, all samples produced a U-Pb dataset characterized by a cluster of datapoints concordant within their uncertainty with usually one array of discordant datapoints intercepting the cluster of concordant points at its lower intercept (Figs. 12 and 13). These discordant datapoints clearly reflect a higher proportion of common $\mathrm{Pb}$ within these analyses. To calculate a model (common $\mathrm{Pb}$ corrected) date for such grains each analysis is individually anchored to common $\mathrm{Pb}$ with a ${ }^{207} \mathrm{~Pb} /{ }^{206} \mathrm{~Pb}$ ratio of $0.844( \pm 2 \%)$ representing the average common $\mathrm{Pb}$ composition for the Mesozoic and Cenozoic time interval (251 Ma to present) calculated using the Stacey-Kramers (1975) model. Two probability density diagrams for each sample are shown in Figs. 12 and 13 that illustrate the concordant and concordant plus the projected data, with similar conclusions drawn using either. Caution should be exercised when interpreting significance of single datapoints that after projection do not overlap with a population of originally concordant datapoints. It should also be noted that this projection of data relies on the fundamental assumption that the only contribution to the offset from concordance is common $\mathrm{Pb}$ and assumes concordancy in the final result. However, this is likely more valid as an assumption for rutile than for zircons for example, where multiple age components are more likely to be preserved and $\mathrm{Pb}$-loss is proven to occur with significant effect. 
Both samples from British Columbia (BC-04g66 and BC-04g67, Fig. 12) show a PaleoceneEocene rutile age distribution ( $\sim 42$ to $77 \mathrm{Ma}$ ) with main clusters at $\sim 52$ and $\sim 48 \mathrm{Ma}$ for the Columbia River and the Eagle River, respectively, reflecting the documented age of the Cordilleran metamorphism that affected the source areas drained by the two rivers. The youngest detrital rutile dates at $\sim 42 \mathrm{Ma}$ indicate that an area of the Monashee complex was still cooling through $\sim 500{ }^{\circ} \mathrm{C}$ at the time. The somewhat older few ages observed are entirely reasonable since these grains could have come from high structural levels of the Monashee Complex in which late Cretaceous metamorphic events are known, or more likely from metamorphic sources in the Selkirk Mountains to the east of the Monashee Complex, still within the drainage area of the Columbia River.

For the modern river sand samples from Bhutan (Fig. 13), the initial number of spot ablations was 40-50 (using a $50 \mu \mathrm{m}$ spot size) and 60-70 (using a 35-40 $\mu \mathrm{m}$ spot size, due to smaller sample grain size) per sample, resulting in a final average age distribution (after eliminating analyses that failed) of $\sim 40$ individual grains in both cases.

The Mo Chu (sample BH0108) drains the northern highest-grade part of the GH in Bhutan and shows a narrow detrital age distribution clustered around 13-15 Ma. For the downstream Puna Tsang Chu (sample LB09-03), the age range is wider ( 10 to $26 \mathrm{Ma}$ ), with the main age cluster slightly older than in the Mo Chu. Narrow age clusters are shown by the Mau Khola (sample LB09-02) at 13 Ma and by the Mangdi Chu (LB09-01), the easternmost of the samples, at $10 \mathrm{Ma}$. We emphasize that no pre-screening e.g. based on the $U$ content of the samples was applied, thereby more robustly representing a genuine sampling of the rutile population in the samples and avoiding bias. Although the detection limit of any instrumental set up will inevitably bias the original population towards the higher radiogenic grains, the number of grains we omitted post-analysis was smaller than if a pre-screening threshold e.g. of 5 ppm U had been applied (Zack et al., 2011). As an example, 37 spots where originally ablated for sample LB09-01, and only 2 of these rejected due to ${ }^{207} \mathrm{~Pb}$ being below the detection limit, while 11 grains $(30 \%)$ with $U<5$ ppm were successfully analysed (Table B, Supplementary data file).The results show that drainages with bedrock predominantly comprised of high grade $\mathrm{GH}$ rocks yield rutile $\mathrm{U}-\mathrm{Pb}$ ages of 10-20 Ma. Zircons from the same samples are primarily $>480 \mathrm{Ma}$, with only a few grains or metamorphic rims reflecting the Himalayan Miocene metamorphism (Bracciali, unpublished data). The contrast between zircon and rutile signatures is very dramatic and as such provides important complementary 
information about the events within the himalayan orogen affected by a complex polyphase history.

\section{Acknowledgements}

This work was funded by NERC grants NE/F01807X/1 to Najman and NE/ F017588/1 to Parrish. We thank Craig Storey (University of Portsmouth) for the trace element data acquisition and Thomas Zack for providing fragments of R10 and R19 rutiles. The Editor Klaus Mezger and two anonimous reviewers are kindly acknowledged for their comments that allowed us to improve the manuscript.

\section{Appendix A. Supplementary data}

Supplementary data associated with this article can be found, in the online version, at doi: $\operatorname{xxxxxxx}$

\section{References}

Allen, C.M. and Campbell, I.H., 2007. Spot dating of detrital rutile by LA-Q-ICP-MS: a powerful provenance tool, GSA Denver Annual Meeting 28-31 October 2007, Paper no. 196-12.

Baldwin, J.A., Bowring, S.A., Williams, M.L. and Williams, I.S., 2004. Eclogites of the Snowbird tectonic zone: petrological and U-Pb geochronological evidence for Paleoproterozoic high-pressure metamorphism in the western Canadian Shield. Contributions to Mineralogy and Petrology 147, 528-548.

Birch, W.D., Barron, L.M., Magee, C. and Sutherland, F.L., 2007. Gold- and diamondbearing White Hills Gravel, St Arnaud district, Victoria: age and provenance based on U$\mathrm{Pb}$ dating of zircon and rutile. Australian Journal of Earth Sciences 54, 609-628.

Black, L.P. and Gulson, B.L., 1978. The age of the Mud Tank carbonatite, Strangways Range, Northern Territory. BMR Journal of Australian Geology and Geophysics 3, 227-232.

Blackburn, T., Bowring, S., Schoene, B., Mahan, K. and Dudas, F., 2011. U-Pb thermochronology: creating a temporal record of lithosphere thermal evolution. Contributions to Mineralogy and Petrology 162, 479-500.

Blackburn, T.J., Bowring, S.A., Perron, J.T., Mahan, K.H., Dudas, F.O. and Barnhart, K.R., 2012. An Exhumation History of Continents over Billion-Year Time Scales. Science 335 , 73-76.

Carruzzo, S., Clarke, D.B., Pelrine, K.M. and MacDonald, M.A., 2006. Texture, composition, and origin of rutile in the South Mountain Batholith, Nova Scotia. The Canadian Mineralogist 44, 715-729. 
Cherniak, D.J., 2000. Pb diffusion in rutile. Contributions to Mineralogy and Petrology 139, 198-207.

Clark, D.J., Hensen, B.J. and Kinny, P.D., 2000. Geochronological constraints for a two-stage history of the Albany-Fraser Orogen, Western Australia. Precambrian Research 102, 155183.

Corfu, F. and Andrews, A.J., 1986. A U-Pb age for mineralized Nipissing diabase, Gowganda, Ontario. Canadian Journal of Earth Sciences 23, 107-109.

Corfu, F. and Muir, T.L., 1989. The Hemlo-Heron Bay greenstone belt and Hemlo Au-Mo deposit, Superior Province, Ontario, Canada 2. Timing of metamorphism, alteration and $\mathrm{Au}$ mineralization from titanite, rutile, and monazite U-Pb geochronology. Chemical Geology: Isotope Geoscience section 79, 201-223.

Cox, R.A., Indares, A. and Dunning, G.R., 2002. Temperature-time paths in the high-P Manicouagan Imbricate zone, eastern Grenville Province: Evidence for two metamorphic events. Precambrian Research 117, 225-250.

Crowley and Parrish, 1999. U-Pb isotopic constraints on diachronous metamorphism in the northern Monashee complex, southern Canadian Cordillera. Journal of Metamorphic Geology 17, 483-502.

Davis, W.J., 1997. U-Pb zircon and rutile ages from granulite xenoliths in the Slave province: Evidence for mafic magmatism in the lower crust coincident with Proterozoic dike swarms. Geology 25, 343-346.

Dodson, M.H., 1973. Closure temperature in cooling geochronological and petrological systems. Contributions to Mineralogy and Petrology 40, 259-274.

Dodson, M.H., 1986. Closure profiles in cooling systems. Materials Science Forum 7, 145154.

Ewing, T.A., Rubatto, D., Eggins, S.M. and Hermann, J., 2011. In situ measurement of hafnium isotopes in rutile by LA-C-ICPMS: Protocol and applications. Chemical Geology 281, 72-82.

Ferry, J. and Watson, E., 2007. New thermodynamic models and revised calibrations for the Ti-in-zircon and Zr-in-rutile thermometers. Contributions to Mineralogy and Petrology 154, 429-437.

Flowers, R.M., Bowring, S.A., Tulloch, A.J., Klepeis, K.A., 2005. Tempo of burial and exhumation within the deep roots of a magmatic arc, Fiordland, New Zealand. Geology 33, 17-20.

Flowers, R.M. et al., 2006. Multistage exhumation and juxtaposition of lower continental crust in the western Canadian Shield: Linking high-resolution U-Pb and ${ }^{40} \mathrm{Ar} /{ }^{39} \mathrm{Ar}$ thermochronometry with pressure-temperature-deformation paths. Tectonics 25, TC4003.

Gansser, A., 1983. Geology of the Bhutan Himalaya. Birkhauser Verlag, Basel, 181 pp. 
Gerstenberger, H. and Haase, G., 1997. A highly effective emitter substance for mass spectrometric $\mathrm{Pb}$ isotope ratio determinations. Chemical Geology 136, 309-312.

Gervais, F.1. and Brown, R.L., 2011. Testing modes of exhumation in collisional orogens: Synconvergent channel flow in the southeastern Canadian Cordillera. Lithosphere 3, 5575.

Grujic, D., Hollister, L.S. and Parrish, R.R., 2002. Himalayan metamorphic sequence as an orogenic channel: insight from Bhutan. Earth and Planetary Science Letters 198, 177191.

Hanmer, S., Parrish, R., Williams, M. and Kopf, C., 1994. Striding-Athabasca mylonite zone: Complex Archean deep-crustal deformation in the East Athabasca mylonite triangle, northern Saskatchewan. Canadian Journal of Earth Sciences 31, 1287-1300.

Harrison, T.M., Trail, D., Schmitt, A.K. and Watson, E.B., 2007. Rutile ${ }^{207} \mathrm{~Pb}-{ }^{206} \mathrm{~Pb}$ ages in the Jack Hills quartzite, Western Australia. Geochimica et Cosmochimica Acta, 71 (15, Supplement 1), A383.

Hinchey, A.M., Carr, S.D., McNeill, P.D. and Rayner, N., 2006. PaleoceneEocene high-grade metamorphism, anatexis, and deformation in the ThorOdin dome, Monashee complex, southeastern British Columbia. Canadian Journal of Earth Sciences 43, 1341-1365.

Hodges, K.V., 2000. Tectonics of the Himalaya and southern Tibet from two perspectives. Geological Society of America Bulletin 112, 324-350.

Hollister, L.S. and Grujic, D., 2006. Pulsed channel flow in Bhutan. In: R.D. Law, M. Searle and L. Godin (Eds.), Channel Flow, Extrusion and Exhumation of Lower-mid Crust in Continental Collision Zones. Geological Society of London Special Publications, pp. 415-423.

Horstwood, M.S.A., Foster, G.L., Parrish, R.R., Noble, S.R. and Nowell, G.M., 2003. Common- $\mathrm{Pb}$ corrected in situ $\mathrm{U}-\mathrm{Pb}$ accessory mineral geochronology by LA-MC-ICPMS. Journal of Analytical Atomic Spectrometry 18, 837-846.

Jackson, S.E., Pearson, N.J., Griffin, W.L. and Belousova, E.A., 2004. The application of laser ablation-inductively coupled plasma-mass spectrometry to in situ U-Pb zircon geochronology. Chemical Geology 211, 47-69.

Jaffey, A.H., Flynn, K.F., Glendenin, L.E., Bentley, W.C., Essling, A.M., 1971. Precision Measurement of Half-Lives and Specific Activities of ${ }^{235} \mathrm{U}$ and ${ }^{238} \mathrm{U}$. Physical Review C, 4, 1889-1906.

Kooijman, E., Mezger, K. and Berndt, J., 2010. Constraints on the U-Pb systematics of metamorphic rutile from in situ LA-ICP-MS analysis. Earth and Planetary Science Letters 293, 321-330.

Kylander-Clark, A.R.C., Hacker, B.R. and Mattinson, J.M., 2008. Slow exhumation of UHP terranes: Titanite and rutile ages of the Western Gneiss Region, Norway. Earth and Planetary Science Letters 272, 531-540. 
Li, Q.-1., Lin, W., Su, W., Li, X.-h., Shi, Y.-h., Liu, Y. and Tang, G.-q., 2011. SIMS U-Pb rutile age of low-temperature eclogites from southwestern Chinese Tianshan, NW China. Lithos 122, 76-86.

Ludwig, K. and Cooper, J., 1984. Geochronology of Precambrian granites and associated UTi-Th mineralization, northern Olary province, South Australia. Contributions to Mineralogy and Petrology 86, 298-308.

Ludwig, K.R., 2003. Isoplot/Ex Version 3.00: A Geochronological Toolkit for Microsoft Excel. Berkeley Geochronology Center, Berkeley, CA.

Luvizotto, G.L. et al., 2009. Rutile crystals as potential trace element and isotope mineral standards for microanalysis. Chemical Geology 261, 346-369.

McQuarrie, N., Robinson, D., Long, S., Tobgay, T., Grujic, D., Gehrels, G. and Ducea, M., 2008. Preliminary stratigraphic and structural architecture of Bhutan: Implications for the along strike architecture of the Himalayan system. Earth and Planetary Science Letters 272, 105-117.

Meinhold, G., Anders, B., Kostopoulos, D. and Reischmann, T., 2008. Rutile chemistry and thermometry as provenance indicator: An example from Chios Island, Greece. Sedimentary Geology 203, 98-111.

Meinhold, G., 2010. Rutile and its applications in earth sciences. Earth-Science Reviews 102, $1-28$.

Meinhold, G., Morton, A.C., Fanning, C.M. and Whitham, A.G., 2011. U-Pb SHRIMP ages of detrital granulite-facies rutiles: further constraints on provenance of Jurassic sandstones on the Norwegian margin. Geological Magazine 148, 473-480.

Meyer, M., John, T., Brandt, S.n. and Klemd, R., 2011, Trace element composition of rutile and the application of Zr-in-rutile thermometry to UHT metamorphism (Epupa Complex, NW Namibia). Lithos 126, 388-401.

Mezger, K., Hanson, G.N. and Bohlen, S.R., 1989. High-precision U-Pb ages of metamorphic rutile: application to the cooling history of high-grade terranes. Earth and Planetary Science Letters 96, 106-118.

Morton, A. and Chenery, S., 2009. Detrital Rutile Geochemistry and Thermometry as Guides to Provenance of Jurassic-Paleocene Sandstones of the Norwegian Sea. Journal of Sedimentary Research 79, 540-553.

Najman, Y. et al., 2010. Timing of India-Asia collision: Geological, biostratigraphic, and palaeomagnetic constraints. J. Geophys. Res. 115, B12416.

Okay, N., Zack, T., Okay, A.I. and Barth, M., 2011. Sinistral transport along the TransEuropean Suture Zone: detrital zircon-rutile geochronology and sandstone petrography from the Carboniferous flysch of the Pontides. Geological Magazine 148, 380-403.

Parrish, R.R., 1989. U-Pb geochronology of the Cape Smith Belt and Sugluk block, northern Quebec. 1989. 
Parrish, R.R., 1995. Thermal evolution of the southeastern Canadian Cordillera. Canadian Journal of Earth Sciences 32, 1618-1642.

Parrish, R.R., Carr, S.D. and Parkinson, D.L., 1988. Eocene extensional tectonics and geochronology of the Southern Omineca Belt, British Columbia and Washington. Tectonics 7, 181-212.

Pearce, N.J.G. et al., 1997. A Compilation of New and Published Major and Trace Element Data for NIST SRM 610 and NIST SRM 612 Glass Reference Materials. Geostandards Newsletter 21, 115-144.

Rösel, D., Zack, T., Barth, M., Möller, A. and Oalmann, J., 2011. U/Pb Age Spectra of Detrital Rutile as a Powerful Tool for Provenance Analysis, Goldschmidt Conference, Prague.

Rudnick, R.L., Barth, M., Horn, I., McDonough, W.F., 2000. Rutile-Bearing Refractory Eclogites: Missing Link Between Continents and Depleted Mantle. Science 287, 278281.

Schärer, U., Krogh, T.E. and Gower, C.F., 1986. Age and evolution of the Grenville Province in eastern Labrador from $\mathrm{U}-\mathrm{Pb}$ systematics in accessory minerals. Contributions to Mineralogy and Petrology 94, 438-451.

Schmitt, A.K., Zack, T., 2012. High-sensitivity U-Pb rutile dating by secondary ion mass spectrometry (SIMS) with an O2+ primary beam. Chemical Geology 332-333, 65-73.

Schmitz, M. and Bowring, S., 2003. Constraints on the thermal evolution of continental lithosphere from $\mathrm{U}-\mathrm{Pb}$ accessory mineral thermochronometry of lower crustal xenoliths, southern Africa. Contributions to Mineralogy and Petrology 144, 592-618.

Schmitz, M.D. and Schoene, B., 2007. Derivation of isotope ratios, errors, and error correlations for U-Pb geochronology using ${ }^{205} \mathrm{~Pb}^{235} \mathrm{U}-\left({ }^{233} \mathrm{U}\right)$-spiked isotope dilution thermal ionization mass spectrometric data. Geochem. Geophys. Geosyst. 8, Q08006.

Sircombe, K., 1995. SHRIMP ion probe provenance studies of heavy detrital minerals in coastal sands and sedimentary rocks of east Australia. Third Australian Conference on Geochronology and Isotope Geoscience, Abstracts, 32.

Sláma, J. et al., 2008. Plešovice zircon - A new natural reference material for U-Pb and $\mathrm{Hf}$ isotopic microanalysis. Chemical Geology 249, 1-35.

Stacey, J.S. and Kramers, J.D., 1975. Approximation of terrestrial lead isotope evolution by a two-stage model. Earth and Planetary Science Letters 26, 207-221.

Storey, C.D., Smith, M.P. and Jeffries, T.E., 2007. In situ LA-ICP-MS U-Pb dating of metavolcanics of Norrbotten, Sweden: Records of extended geological histories in complex titanite grains. Chemical Geology 240, 163-181.

Taylor, R., Clark, C., Reddy, S.M., 2012. The effect of grain orientation on secondary ion mass spectrometry (SIMS) analysis of rutile. Chemical Geology 300-301, 81-87. 
Thomas, R.J. et al., 2010. The Mecubúri and Alto Benfica Groups, NE Mozambique: Aids to unravelling ca. 1 and 0.5 Ga events in the East African Orogen. Precambrian Research 178, 72-90.

Tomkins, H.S., Powell, R. and Ellis, D.J., 2007. The pressure dependence of the zirconiumin-rutile thermometer. Journal of Metamorphic Geology 25, 703-713.

Treloar, P.J., O'Brien, P.J., Parrish, R.R. and Khan, M.A., 2003. Exhumation of early Tertiary, coesite-bearing eclogites from the Pakistan Himalaya. Journal of the Geological Society 160, 367-376.

Triebold, S., von Eynatten, H., Luvizotto, G.L. and Zack, T., 2007. Deducing source rock lithology from detrital rutile geochemistry: An example from the Erzgebirge, Germany. Chemical Geology 244, 421-436.

Vry, J.K. and Baker, J.A., 2006. LA-MC-ICPMS Pb-Pb dating of rutile from slowly cooled granulites: Confirmation of the high closure temperature for $\mathrm{Pb}$ diffusion in rutile. Geochimica et Cosmochimica Acta 70, 1807-1820.

Watson, E., Wark, D. and Thomas, J., 2006. Crystallization thermometers for zircon and rutile. Contributions to Mineralogy and Petrology 151, 413-433.

Wiedenbeck, M. et al., 1995. Three natural zircon standards for U-Th-Pb, Lu-Hf, trace element and REE analyses. Geostandards Newsletter 19, 1-23.

Zack, T., von Eynatten, H. and Kronz, A., 2004a. Rutile geochemistry and its potential use in quantitative provenance studies. Sedimentary Geology 171, 37-58.

Zack, T., Moraes, R. and Kronz, A., 2004b. Temperature dependence of Zr in rutile: empirical calibration of a rutile thermometer. Contributions to Mineralogy and Petrology 148, 471488.

Zack, T., Stockli, D., Luvizotto, G., Barth, M., Belousova, E., Wolfe, M. and Hinton, R., 2011. In situ U-Pb rutile dating by LA-ICP-MS: ${ }^{208} \mathrm{~Pb}$ correction and prospects for geological applications. Contributions to Mineralogy and Petrology 162, 515-530. 
Table 1

Trace element composition of rutile (ppm; LA-quad-ICP-MS data).

\begin{tabular}{|c|c|c|c|c|c|c|c|c|c|c|c|c|c|c|c|c|}
\hline & $\mathrm{Al}$ & Sc & $\mathrm{V}$ & $\mathrm{Cr}$ & $\mathrm{Zr}$ & $\mathrm{Nb}$ & Mo & Sn & $\mathrm{Hf}$ & $\mathrm{Ta}$ & W & $\mathrm{U}$ & $\mathrm{Pb}$ & $\mathrm{Zr} / \mathrm{Hf}$ & $\mathrm{Nb} / \mathrm{Ta}$ & $\mathrm{Cr} / \mathrm{Nb}$ \\
\hline $\begin{array}{c}\text { measured } \\
\text { mass }\end{array}$ & 27 & 45 & 51 & 52 & 90 & 93 & 95 & 118 & 177 & 181 & 182 & 238 & (b) & - & - & - \\
\hline (a) & 20 & 8 & 5 & 4 & 6 & 4 & 8 & 7 & 7 & 9 & 21 & 7 & 10 & 9 & 10 & 6 \\
\hline \multicolumn{17}{|c|}{ Sugluk-4, granulite facies quartzite, Sugluk group, $62^{\circ} 16.9^{\prime} \mathrm{N}, 75^{\circ} 37.3^{\prime} \mathrm{W}$} \\
\hline r500_a & 57 & 24 & 2010 & 1140 & 783 & 1550 & 65 & 30 & 49 & 176 & 226 & 95 & - & 16 & 9 & 0.74 \\
\hline$r 500 \_b$ & 76 & 24 & 2090 & 1200 & 882 & 1600 & 73 & 33 & 55 & 177 & 230 & 96 & - & 16 & 9 & 0.75 \\
\hline r500_c & 39 & 24 & 2090 & 1130 & 869 & 1630 & 66 & 32 & 56 & 162 & 214 & 96 & - & 16 & 10 & 0.69 \\
\hline r500_d & 39 & 25 & 2010 & 1100 & 821 & 1530 & 73 & 33 & 52 & 164 & 223 & 96 & - & 16 & 9 & 0.72 \\
\hline r500_f & 66 & 24 & 2150 & 1140 & 658 & 1620 & 71 & 35 & 42 & 174 & 237 & 98 & - & 16 & 9 & 0.70 \\
\hline r6_A & 29 & 4.9 & 2930 & 798 & 666 & 1150 & 67 & 28 & 36 & 19 & 5 & 24 & 10 & 19 & 62 & 0.69 \\
\hline r6_B & 65 & 5.3 & 3230 & 804 & 699 & 1240 & 59 & 30 & 41 & 40 & 11 & 25 & 10 & 17 & 31 & 0.65 \\
\hline r6_C & 42 & 5.5 & 3030 & 813 & 676 & 1300 & 63 & 31 & 41 & 57 & 14 & 24 & 10 & 16 & 23 & 0.63 \\
\hline r6_D & 30 & 5.2 & 3070 & 788 & 602 & 1300 & 71 & 30 & 37 & 63 & 18 & 24 & 10 & 16 & 21 & 0.61 \\
\hline r7_A & 89 & 14 & 1700 & 940 & 686 & 1760 & 41 & 30 & 43 & 151 & 207 & 81 & 33 & 16 & 12 & 0.53 \\
\hline r7_B & 67 & 16 & 1730 & 899 & 710 & 1690 & 41 & 30 & 43 & 132 & 184 & 78 & 32 & 17 & 13 & 0.53 \\
\hline r7_C & 60 & 12 & 1680 & 941 & 797 & 1690 & 40 & 29 & 49 & 124 & 182 & 79 & 32 & 16 & 14 & 0.56 \\
\hline r7_D & 31 & 19 & 1760 & 965 & 832 & 1690 & 42 & 30 & 49 & 117 & 164 & 78 & 32 & 17 & 14 & 0.57 \\
\hline r11_A & 48 & 3.4 & 1880 & 666 & 882 & 1140 & 36 & 26 & 59 & 25 & 5 & 27 & 11 & 15 & 47 & 0.58 \\
\hline r11_B & 44 & 3.5 & 1950 & 629 & 919 & 1340 & 38 & 31 & 58 & 31 & 6 & 27 & 11 & 16 & 43 & 0.47 \\
\hline r11_C & 58 & 4.1 & 1950 & 590 & 842 & 1250 & 41 & 26 & 54 & 42 & 6 & 25 & 10 & 16 & 30 & 0.47 \\
\hline r13_A & 20 & 5.8 & 2580 & 715 & 730 & 1250 & 47 & 28 & 44 & 82 & 10 & 25 & 9 & 17 & 15 & 0.57 \\
\hline r13_B & 27 & 4.9 & 2490 & 713 & 721 & 1190 & 48 & 27 & 45 & 76 & 10 & 25 & 10 & 16 & 16 & 0.60 \\
\hline r13_C & 42 & 4.9 & 2600 & 711 & 732 & 1300 & 51 & 28 & 44 & 82 & 11 & 26 & 10 & 17 & 16 & 0.55 \\
\hline r18_A & 7 & 3.0 & 5980 & 1450 & 1020 & 1540 & 33 & 37 & 66 & 123 & 762 & 81 & - & 16 & 13 & 0.94 \\
\hline r18_B & 12 & 3.0 & 5690 & 1410 & 1020 & 1480 & 33 & 33 & 66 & 125 & 774 & 82 & - & 16 & 12 & 0.95 \\
\hline r18_C & 13 & 3.6 & 6150 & 1410 & 1030 & 1490 & 35 & 37 & 65 & 126 & 765 & 80 & - & 16 & 12 & 0.95 \\
\hline r18_D & 13 & 3.2 & 5720 & 1400 & 1060 & 1530 & 32 & 34 & 67 & 128 & 789 & 78 & - & 16 & 12 & 0.92 \\
\hline r18_E & 5 & 3.5 & 5570 & 1420 & 941 & 1490 & 37 & 35 & 60 & 140 & 803 & 80 & - & 16 & 11 & 0.95 \\
\hline r502_A & 35 & 12 & 2460 & 840 & 657 & 1850 & 46 & 30 & 44 & 123 & 153 & 80 & - & 15 & 15 & 0.45 \\
\hline r502_B & 43 & 11 & 2590 & 804 & 694 & 1740 & 46 & 30 & 48 & 149 & 178 & 78 & - & 14 & 12 & 0.46 \\
\hline r504_A & 75 & 5.8 & 2960 & 869 & 1230 & 1260 & 47 & 31 & 60 & 63 & 5 & 29 & - & 20 & 20 & 0.69 \\
\hline r504_B & 28 & 5.3 & 3190 & 916 & 1260 & 1300 & 50 & 32 & 63 & 75 & 5 & 29 & - & 20 & 17 & 0.70 \\
\hline
\end{tabular}

PCA-S207, granulite facies garnet-bearing paragneiss, East Atabasca Mylonite triangle, 59॰21.6' $\mathrm{N}, 106^{\circ} 1.7^{\prime} \mathrm{W}$

\begin{tabular}{|c|c|c|c|c|c|c|c|c|c|c|c|c|c|c|c|c|}
\hline $500 \_a$ & 78 & 1.3 & 4890 & 1340 & 770 & 762 & 14 & 5.6 & 21 & 10 & 5 & 39 & - & 37 & 75 & 1.76 \\
\hline r500_b & 73 & 1.5 & 4700 & 1290 & 799 & 766 & 15 & 5.0 & 23 & 14 & 8 & 38 & - & 35 & 56 & 1.68 \\
\hline r500_c & 59 & 1.4 & 4750 & 1360 & 819 & 785 & 14 & 5.6 & 26 & 16 & 10 & 39 & - & 32 & 48 & 1.73 \\
\hline r500_d & 49 & 1.7 & 4740 & 1370 & 847 & 789 & 14 & 5.7 & 26 & 20 & 14 & 38 & - & 33 & 40 & 1.74 \\
\hline r500_e & 53 & 1.4 & 4890 & 1310 & 825 & 788 & 14 & 5.5 & 26 & 19 & 16 & 40 & - & 32 & 41 & 1.66 \\
\hline r500_f & 111 & 1.4 & 4800 & 1340 & 823 & 785 & 15 & 5.0 & 25 & 15 & 10 & 40 & - & 33 & 51 & 1.71 \\
\hline r500_g & 128 & 1.2 & 4580 & 1310 & 813 & 789 & 12 & 5.5 & 25 & 15 & 10 & 40 & - & 32 & 52 & 1.66 \\
\hline r500_h & 68 & 1.4 & 4850 & 1300 & 801 & 752 & 13 & 5.0 & 24 & 14 & 8 & 37 & - & 34 & 53 & 1.73 \\
\hline r7_A & 92 & 1.6 & 2760 & 961 & 1300 & 1930 & 44 & 8.1 & 57 & 69 & 29 & 17 & 7 & 23 & 28 & 0.50 \\
\hline r7_B & 98 & 1.8 & 2780 & 983 & 1350 & 1960 & 42 & 7.3 & 60 & 87 & 39 & 18 & 7 & 23 & 22 & 0.50 \\
\hline r7_C & 88 & 2.1 & 2790 & 887 & 1320 & 1960 & 38 & 7.4 & 60 & 123 & 49 & 17 & 7 & 22 & 16 & 0.45 \\
\hline r7_D & 85 & 2.6 & 2850 & 919 & 1260 & 1960 & 23 & 9.1 & 57 & 130 & 54 & 18 & 7 & 22 & 15 & 0.47 \\
\hline r7_E & 88 & 1.7 & 2720 & 899 & 1150 & 1870 & 42 & 7.7 & 39 & 24 & 3 & 17 & 7 & 29 & 78 & 0.48 \\
\hline r7_F & 94 & 1.9 & 2680 & 893 & 1260 & 1900 & 41 & 7.8 & 49 & 47 & 15 & 17 & 7 & 26 & 41 & 0.47 \\
\hline r7_G & 101 & 1.8 & 2740 & 915 & 1380 & 1930 & 40 & 8.1 & 58 & 73 & 33 & 18 & 7 & 24 & 26 & 0.47 \\
\hline r8_A & 65 & 1.7 & 4030 & 1350 & 542 & 1510 & 28 & 4.9 & 22 & 33 & 5 & 18 & 9 & 24 & 46 & 0.89 \\
\hline r8_B & 42 & 2.1 & 3950 & 1390 & 577 & 1420 & 25 & 3.5 & 25 & 31 & 11 & 20 & 10 & 24 & 46 & 0.98 \\
\hline r8_C & 41 & 2.2 & 4100 & 1520 & 704 & 1450 & 27 & 3.8 & 31 & 38 & 19 & 23 & 10 & 23 & 39 & 1.05 \\
\hline r8_D & 36 & 1.9 & 4100 & 1400 & 911 & 1650 & 27 & 4.2 & 41 & 75 & 20 & 23 & 10 & 22 & 22 & 0.85 \\
\hline r8_F & 36 & 1.7 & 3920 & 1420 & 758 & 1590 & 27 & 4.5 & 36 & 70 & 21 & 18 & 8 & 21 & 23 & 0.89 \\
\hline r9_A & 74 & 1.1 & 4360 & 1460 & 1180 & 1390 & 22 & 8.4 & 47 & 80 & 27 & 23 & 9 & 25 & 17 & 1.05 \\
\hline r9_B & 69 & 1.4 & 4390 & 1590 & 1150 & 1430 & 22 & 7.7 & 46 & 82 & 29 & 23 & 9 & 25 & 17 & 1.11 \\
\hline r10_A & 53 & 1.6 & 4790 & 876 & 663 & 569 & 12 & 6.9 & 23 & 30 & 7 & 20 & 9 & 29 & 19 & 1.54 \\
\hline r10_B & 124 & 1.7 & 4800 & 863 & 627 & 561 & 10 & 6.7 & 20 & 20 & 4 & 19 & 8 & 32 & 28 & 1.54 \\
\hline r10_C & 55 & 2.3 & 4690 & 818 & 645 & 584 & 12 & 6.7 & 20 & 16 & 4 & 19 & 8 & 32 & 37 & 1.40 \\
\hline r11_A & 49 & 1.4 & 4390 & 1440 & 1210 & 1310 & 58 & 5.6 & 42 & 80 & 37 & 15 & 6 & 29 & 16 & 1.10 \\
\hline r11_B & 180 & 1.4 & 4830 & 1490 & 1360 & 1280 & 52 & 7.0 & 49 & 55 & 24 & 15 & 6 & 28 & 23 & 1.16 \\
\hline r11_C & 82 & 1.1 & 4610 & 1480 & 1390 & 1200 & 59 & 6.6 & 51 & 38 & 11 & 15 & 6 & 27 & 32 & 1.23 \\
\hline r501_A & 66 & 1.2 & 4240 & 1420 & 1000 & 1790 & 49 & 8.1 & 36 & 40 & 7 & 14 & - & 28 & 45 & 0.79 \\
\hline r501_B & 46 & 2.4 & 4410 & 1040 & 945 & 1600 & 20 & 6.7 & 31 & 29 & 7 & 15 & - & 30 & 55 & 0.65 \\
\hline r503_A & 76 & 1.5 & 5420 & 1690 & 1040 & 1540 & 37 & 4.8 & 49 & 66 & 24 & 19 & - & 21 & 23 & 1.10 \\
\hline r503_B & 69 & 1.4 & 5390 & 1740 & 1090 & 1570 & 30 & 3.8 & 50 & 81 & 32 & 20 & - & 22 & 19 & 1.11 \\
\hline 04_A & 59 & 1.2 & 4310 & 1190 & 955 & 431 & 20 & 4.8 & 31 & 12 & 7 & 12 & - & 31 & 37 & 2.76 \\
\hline 4_B & 55 & 1.2 & 4530 & 1250 & 970 & 433 & 18 & 5.0 & 30 & 13 & 8 & 12 & - & 33 & 35 & .89 \\
\hline
\end{tabular}

(a) external reproducibility (1SD)

(b) $\mathrm{Pb}={ }^{206} \mathrm{~Pb}+{ }^{207} \mathrm{~Pb}$ as measured by LA-MC-ICP-MS, ignoring ${ }^{204} \mathrm{~Pb}$ and ${ }^{208} \mathrm{~Pb}$ (the latter b.d.I. of LA-quad-ICP-MS) which together are much less than $1 \%$ of total $\mathrm{Pb}$ 
Table 2

$T$ as a function of $Z$ r-in-rutile at $P=6 \mathrm{kbar}$

\begin{tabular}{|c|c|c|c|}
\hline \multirow{2}{*}{$\begin{array}{l}\text { Sugluk-4 } \\
r 6 D\end{array}$} & \multirow{2}{*}{$\frac{\mathrm{T}\left({ }^{\circ} \mathrm{C}\right)^{(\mathrm{a})}}{688}$} & \multicolumn{2}{|c|}{$P C A-S 2 \mathrm{~T}\left({ }^{\circ} \mathrm{C}\right)^{(\mathrm{a})}$} \\
\hline & & $r 8 A$ & 679 \\
\hline$r 502 A$ & 696 & $r 8 B$ & 685 \\
\hline$r 500 \_f$ & 696 & $r \overline{0} B$ & 692 \\
\hline r6_A & 697 & $r 10^{-} C$ & 695 \\
\hline$r 6 \_c$ & 699 & r10_A & 697 \\
\hline$r 7 \_A$ & 700 & $r 8 C$ & 702 \\
\hline$r \overline{502} B$ & 701 & $r 8 \_F$ & 709 \\
\hline$r 6 B$ & 702 & $r 500 a$ & 710 \\
\hline$r 7 \_B$ & 703 & $r 500 \_b$ & 714 \\
\hline$r \overline{3} \_B$ & 704 & r500_h & 714 \\
\hline r13_A & 706 & r500_g & 715 \\
\hline r13_C & 706 & $r 500 \_c$ & 716 \\
\hline$r 500 \_a$ & 712 & $r 500 \_f$ & 716 \\
\hline$r 7 \_\bar{C}$ & 713 & r500_e & 717 \\
\hline$r 500 \_d$ & 716 & r500_d & 719 \\
\hline$r 7 \_D^{-}$ & 717 & $r 8 D_{-}^{-}$ & 726 \\
\hline$r \overline{11} c$ & 719 & $r \overline{501} B$ & 729 \\
\hline$r 500 \_c$ & 721 & r504_A & 730 \\
\hline$r 500 \_b$ & 723 & $r 504 \_B$ & 732 \\
\hline$r 11 \bar{A}$ & 723 & r501_A & 735 \\
\hline$r 11 \_B$ & 727 & r503_A & 738 \\
\hline$r 18 E$ & 729 & $r 503 \_B$ & 743 \\
\hline r18_A & 737 & $r 7 \_E$ & 748 \\
\hline$r 18 \_B$ & 737 & $r 9_{-} B$ & 748 \\
\hline$r 18 c c$ & 737 & $r g_{A} A$ & 751 \\
\hline$r 18 \_D$ & 740 & $r \overline{11} A$ & 753 \\
\hline$r 504 \_A$ & 755 & $r 7 \bar{D}$ & 757 \\
\hline \multirow[t]{7}{*}{$r 504 \_B$} & 757 & $r 7$ & 757 \\
\hline & & $r 7 \_A$ & 760 \\
\hline & & $r 7 c C$ & 762 \\
\hline & & $r 7 \_B$ & 764 \\
\hline & & $r \overline{11} B B$ & 765 \\
\hline & & $r 7 \bar{G}$ & 766 \\
\hline & & $r \overline{11} C$ & 767 \\
\hline
\end{tabular}

(a) (based on the calibration of Tomkins et al., 2007); $\mathrm{T}$ at $\mathrm{P}=10 \mathrm{kbar}$ is $\sim 20^{\circ} \mathrm{C}$ higher than at $6 \mathrm{kbar}$ 


\begin{tabular}{|c|c|c|c|c|c|c|c|c|c|c|c|c|c|c|c|c|c|c|c|c|c|c|c|c|c|c|c|}
\hline \multirow[b]{2}{*}{ (a) } & \multirow[b]{2}{*}{$\begin{array}{l}\frac{T h}{U} \\
\text { (b) }\end{array}$} & \multirow[b]{2}{*}{$\begin{array}{l}{ }^{206} \mathrm{~Pb}^{*} \\
\times 10^{-13} \mathrm{~mol} \\
\text { (c) }\end{array}$} & \multirow[b]{2}{*}{$\begin{array}{c}\mathrm{mol} \% \\
{ }^{206} \mathrm{~Pb}^{*} \\
\text { (c) }\end{array}$} & \multirow[b]{2}{*}{$\begin{array}{l}\frac{\mathrm{Pb}^{*}}{\mathrm{~Pb}_{\mathrm{c}}} \\
\text { (c) }\end{array}$} & \multirow[b]{2}{*}{$\begin{array}{c}\mathrm{Pb}_{\mathrm{c}} \\
(\mathrm{pg}) \\
(\mathrm{c})\end{array}$} & \multirow[b]{2}{*}{$\begin{array}{l}\frac{{ }^{206} \mathrm{~Pb}}{{ }^{204} \mathrm{~Pb}} \\
(\mathrm{~d})\end{array}$} & \multirow[b]{2}{*}{$\begin{array}{c}\frac{{ }^{208} \mathrm{~Pb}}{{ }^{206} \mathrm{~Pb}} \\
(\mathrm{e})\end{array}$} & \multicolumn{6}{|c|}{$\begin{array}{l}\text { Radiogenic Isotope Ratios } \\
{ }^{207} \mathrm{~Pb}\end{array}$} & \multirow[b]{2}{*}{$\begin{array}{l}\text { corr. coef. } \\
{ }^{207} \mathrm{~Pb} / 235 \mathrm{U} \text { - } \\
{ }^{206} \mathrm{~Pb} /{ }^{238} \mathrm{U}\end{array}$} & & \multicolumn{4}{|c|}{ Isotopic Ages } & \multicolumn{7}{|c|}{ Sample (Radiogenic + Initial Pb) Isotope Ratios } \\
\hline & & & & & & & & $\begin{array}{l}\frac{{ }^{207} \mathrm{~Pb}}{{ }^{206} \mathrm{~Pb}} \\
(\mathrm{e})\end{array}$ & $\begin{array}{l}\% \text { err } \\
\text { (f) }\end{array}$ & $\begin{array}{l}\frac{{ }^{207} \mathrm{~Pb}}{{ }^{235} \mathrm{U}} \\
(\mathrm{e})\end{array}$ & $\begin{array}{l}\% \text { err } \\
\text { (f) }\end{array}$ & $\begin{array}{l}\frac{{ }^{206} \mathrm{~Pb}}{{ }^{238} \mathrm{U}} \\
\text { (e) }\end{array}$ & $\begin{array}{c}\% \text { err } \\
\text { (f) }\end{array}$ & & $\begin{array}{l}\frac{{ }^{207} \mathrm{~Pb}}{{ }^{206} \mathrm{~Pb}} \\
(\mathrm{~g})\end{array}$ & $\begin{array}{l} \pm \\
(f)\end{array}$ & $\begin{array}{l}\frac{{ }^{207} \mathrm{~Pb}}{{ }^{235} \mathrm{U}} \\
(\mathrm{g})\end{array}$ & $\begin{array}{l} \pm \\
(f)\end{array}$ & $\begin{array}{c}\frac{{ }^{206} \mathrm{~Pb}}{{ }^{238} \mathrm{U}} \\
(\mathrm{g})\end{array}$ & $\begin{array}{l} \pm \\
(\mathrm{f})\end{array}$ & $\begin{array}{l}\frac{{ }^{238} \mathrm{U}}{{ }^{206} \mathrm{~Pb}} \\
\text { (h) }\end{array}$ & $\begin{array}{l}\% \text { err } \\
\text { (f) }\end{array}$ & $\begin{array}{c}\frac{{ }^{207} \mathrm{~Pb}}{{ }^{206} \mathrm{~Pb}} \\
\text { (h) }\end{array}$ & $\begin{array}{l}\% \text { err } \\
\text { (f) }\end{array}$ & $\begin{array}{c}\frac{{ }^{204} \mathrm{~Pb}}{{ }^{206} \mathrm{~Pb}} \\
\text { (h) }\end{array}$ & $\begin{array}{l}\% \text { err } \\
\text { (f) }\end{array}$ & $\begin{array}{l}\text { corr. coef. } \\
{ }^{238} \mathrm{U} /{ }^{200} \mathrm{~Pb} \text { - } \\
\left.{ }^{207} \mathrm{~Pb}\right|^{206} \mathrm{~Pb}\end{array}$ \\
\hline \multicolumn{28}{|c|}{$\overline{S u g l u k-4}$} \\
\hline rT1 & 0.00 & $\begin{array}{c}184.0 \\
50.0\end{array}$ & $\begin{array}{l}99.83 \\
99.93\end{array}$ & $\begin{array}{l}149 \\
563\end{array}$ & $\begin{array}{c}28.1 \\
3.1\end{array}$ & $\begin{array}{r}9229 \\
23825\end{array}$ & $\begin{array}{l}0.00 \\
0.58\end{array}$ & $\begin{array}{l}0.10531 \\
0.10551\end{array}$ & $\begin{array}{l}0.087 \\
0.063\end{array}$ & $\begin{array}{l}4.4437 \\
4.4680\end{array}$ & $\begin{array}{l}0.18 \\
0.16\end{array}$ & $\begin{array}{l}0.30603 \\
0.30712\end{array}$ & $\begin{array}{l}0.11 \\
0.09\end{array}$ & $\begin{array}{l}0.94 \\
0.95\end{array}$ & $\begin{array}{l}1719.7 \\
1723.2\end{array}$ & $\begin{array}{l}1.6 \\
1.2\end{array}$ & $\begin{array}{l}1720.5 \\
1725.0\end{array}$ & $\begin{array}{l}1.5 \\
1.3\end{array}$ & $\begin{array}{l}1721.2 \\
1726.6\end{array}$ & $\begin{array}{l}1.6 \\
1.4\end{array}$ & $\begin{array}{l}3.2625 \\
3.2552\end{array}$ & $\begin{array}{l}0.11 \\
0.09\end{array}$ & $\begin{array}{l}0.10669 \\
0.10572\end{array}$ & $\begin{array}{c}0.095 \\
0.19\end{array}$ & $\begin{array}{l}0.000101 \\
0.000016\end{array}$ & $\begin{array}{c}3.6 \\
84.1\end{array}$ & $\begin{array}{l}-0.67 \\
-0.59\end{array}$ \\
\hline $\begin{array}{l}\text { rT2 } \\
\text { rT3 }\end{array}$ & $\begin{array}{l}1.99 \\
0.00\end{array}$ & $\begin{array}{l}50.0 \\
17.3\end{array}$ & $\begin{array}{l}99.93 \\
99.77\end{array}$ & 118 & $\begin{array}{l}3.1 \\
3.3\end{array}$ & 7647 & 0.00 & 0.10543 & 0.099 & 4.4076 & 0.18 & 0.30321 & $\begin{array}{l}0.09 \\
0.09\end{array}$ & & 221.7 & 1.8 & 1713.8 & 1.5 & $\begin{array}{l}1 / 26.6 \\
1707.3\end{array}$ & $\begin{array}{l}1.4 \\
1.4\end{array}$ & $\begin{array}{l}3.2552 \\
3.2952\end{array}$ & $\begin{array}{l}0.09 \\
0.11\end{array}$ & .10618 & 0.50 & 0.000055 & $\begin{array}{l}84.1 \\
69.6\end{array}$ & $\begin{array}{l}-0.59 \\
-0.73\end{array}$ \\
\hline $\mathrm{rla}$ & 0.02 & 1.9 & 96.11 & 7 & 6.5 & 425 & 0.00 & 0.10518 & 0.24 & 4.2744 & 0.35 & 0.29474 & 0.16 & & 1717.4 & 4.4 & 1688.5 & 2.9 & 1665.2 & 2.3 & 3.3025 & 0.65 & 0.12832 & 3.6 & .001693 & 19.7 & -0.99 \\
\hline rT5 & 0.00 & 7.4 & 99.57 & 63 & 2.7 & 4132 & 0.00 & 0.10471 & 0.10 & 4.3388 & 0.18 & 0.30052 & 0.09 & & 709.2 & 1.9 & 1700.8 & 1.5 & 1694.0 & 1.4 & 3.3242 & 0.19 & 0.10560 & 1.2 & .000065 & 137.0 & -0.91 \\
\hline rib & 0.00 & 52.2 & 99.71 & 90 & 13.2 & 5607 & 0.00 & 0.10531 & 0.098 & 4.4652 & 0.22 & 0.30753 & 0.16 & & 1719.6 & 1.8 & 1724.5 & 1.8 & 1728.6 & .4 & 3.2439 & 0.16 & 10740 & 0.19 & 000153 & 8.7 & -0.35 \\
\hline 7 & 0. & 31.8 & 99.15 & 30 & 24.1 & 1871 & 0.00 & 0.10540 & 0.10 & 4.4288 & 0.20 & 0.30476 & 0.1 & & 1721.2 & 1.8 & 1717.7 & 1.6 & 1714.9 & 1.7 & 3.2558 & 0.12 & 0.11214 & 0.27 & .000494 & 4.2 & -0.50 \\
\hline rT8 & 0.00 & 23.3 & 99.86 & 196 & 2.71 & 12791 & 0.00 & 0.10557 & 0.085 & 4.4499 & 0.18 & 0.30572 & 0.10 & & 1724.1 & 1.6 & 1721.7 & 1.5 & 1719.7 & 1.6 & 3.2699 & 0.12 & 10586 & 0.38 & 000022 & 129.9 & -0.58 \\
\hline rT9 & 0.00 & 16.8 & 99.72 & 95 & 4.01 & 6105 & 0.00 & 10578 & 0.092 & 4.4558 & 0.17 & 0.30552 & 0.091 & & 1727.7 & 1.7 & 1722.8 & 1.4 & 1718.7 & 1.4 & 3.2687 & 0.12 & 0.10694 & 0.51 & 0.000086 & 45.7 & -0.73 \\
\hline rT10 & 0.00 & 10.9 & 99.63 & 73 & 3.39 & 4716 & 0.00 & 0.10556 & 0.091 & 4.4281 & 0.18 & 0.30425 & 0.089 & 0.97 & 1724.0 & 1.7 & 1717.6 & 1.5 & 1712.4 & 1.3 & 3.2821 & 0.14 & 0.10681 & 0.79 & 0.000092 & 66.0 & -0.84 \\
\hline \multicolumn{28}{|c|}{ PCA-S20 } \\
\hline rT1 & 0.00 & 6.1 & .56 & 10 & 13.6 & 651 & 0.00 & 1452 & 0.15 & 5.2120 & 0.23 & 0.33009 & 0.11 & & 72.2 & 2.6 & 1854.6 & 1.9 & 1838.9 & 1.7 & 9612 & 0.14 & 13389 & 0.53 & 433 & 3.6 & -0.79 \\
\hline & & 41 & & 34 & 2.83 & 2115 & 00 & 393 & 0.097 & 5.1248 & 0.19 & 0.32624 & & & 2.9 & 1.8 & 1840.2 & 1.6 & 1820.2 & 1. & 500 & 0.18 & 818 & 0.91 & 315 & & \\
\hline rT3 & 0.00 & 26.6 & 97.18 & 9 & 68.6 & 558 & 0.00 & 1389 & 0.16 & 5.2076 & 0.23 & 0.33164 & 0.1 & & 1862.2 & 2.8 & 1853.9 & 2.0 & 1846.4 & 1.7 & 2.9314 & 0.09 & 0.13781 & 0.14 & 0.001769 & 0.7 & -0.69 \\
\hline rT4 & 0.08 & 5.0 & 82.33 & 1 & 95.1 & 89 & 0.02 & 0.11405 & 0.78 & 5.2417 & 0.82 & 0.33333 & 0.38 & 0.31 & 1864.8 & 14.2 & 1859.4 & 7.0 & 1854.6 & 6.1 & 2.4748 & 0.16 & 0.26462 & 0.24 & 0.01114 & 0.5 & -0.74 \\
\hline \multirow{2}{*}{\multicolumn{28}{|c|}{$R 10$}} \\
\hline . & & & & & & & & & & & & & & & & 9 & 1085.8 & 1.2 & 1083.73 & 0.85 & & 0.09 & 011 & 0.18 & 225 & & 58 \\
\hline r2 & & 95.4 & 94 & 415 & 5.1 & 27415 & 0.00 & 75800 & 0.10 & 1.9133 & 0.20 & 0.18307 & & & 9.6 & 2.0 & 1085.7 & 1.3 & 1083.8 & 1. & 598 & 0.13 & 0.076221 & 0.061 & 0030 & 11.7 & -0.90 \\
\hline r3 & 0. & 22.3 & .70 & 86 & 5.8 & 5677 & 0.00 & 5726 & 0.089 & 1.9086 & 0.17 & 0.18279 & ( & 0.5 & 87.6 & 1.8 & 1084.1 & 1.1 & 1082.31 & 0.86 & 5.4571 & 0.09 & 0.077813 & 0.28 & 147 & 10.0 & -0.54 \\
\hline 14 & 0.00 & 125.8 & 99.91 & 276 & 10.1 & 18148 & .00 & 075801 & 0.084 & .9179 & 0.17 & .18350 & 0.095 & 196 & 889.6 & 1.7 & 1087.3 & 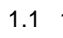 & 6.17 & 0.95 & 5.4449 & 0.09 & 0.076510 & 0.095 & 0.000050 & 5.2 & -0.74 \\
\hline
\end{tabular}

(a) fractions composed of single rutile grains or fragments.

(b) Model Th/ $\mathrm{U}$ ratio calculated from radiogenic ${ }^{208} \mathrm{~Pb} /{ }^{206} \mathrm{~Pb}$ ratio and ${ }^{207} \mathrm{~Pb} /{ }^{235} \mathrm{U}$ age. 0.00 indicates that Th-derived ${ }^{208} \mathrm{~Pb}$ was below detection limit after blank and spike subtraction.

(c) $\mathrm{Pb}^{*}$ and $\mathrm{Pb}_{\mathrm{c}}$ represent radiogenic and common $\mathrm{Pb}$, respectively; $\mathrm{mol} \%{ }^{206} \mathrm{~Pb}^{*}$ with respect to radiogenic, blank and initial common $\mathrm{Pb}$.

(d) Measured ratio corrected for spike and fractionation only. SEM analyses, based on analysis of NBS-981 and NBS-982.

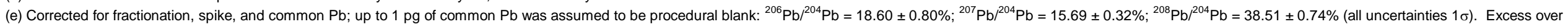
blank was assigned to initial common $\mathrm{Pb}$.

(f) Errors are $2 \sigma$, propagated using the algorithms of Schmitz and Schoene (2007).

(g) Calculations are based on the decay constants of Jaffey et al. (1971).

(h) Corrected for fractionation, spike, and blank Pb only. 


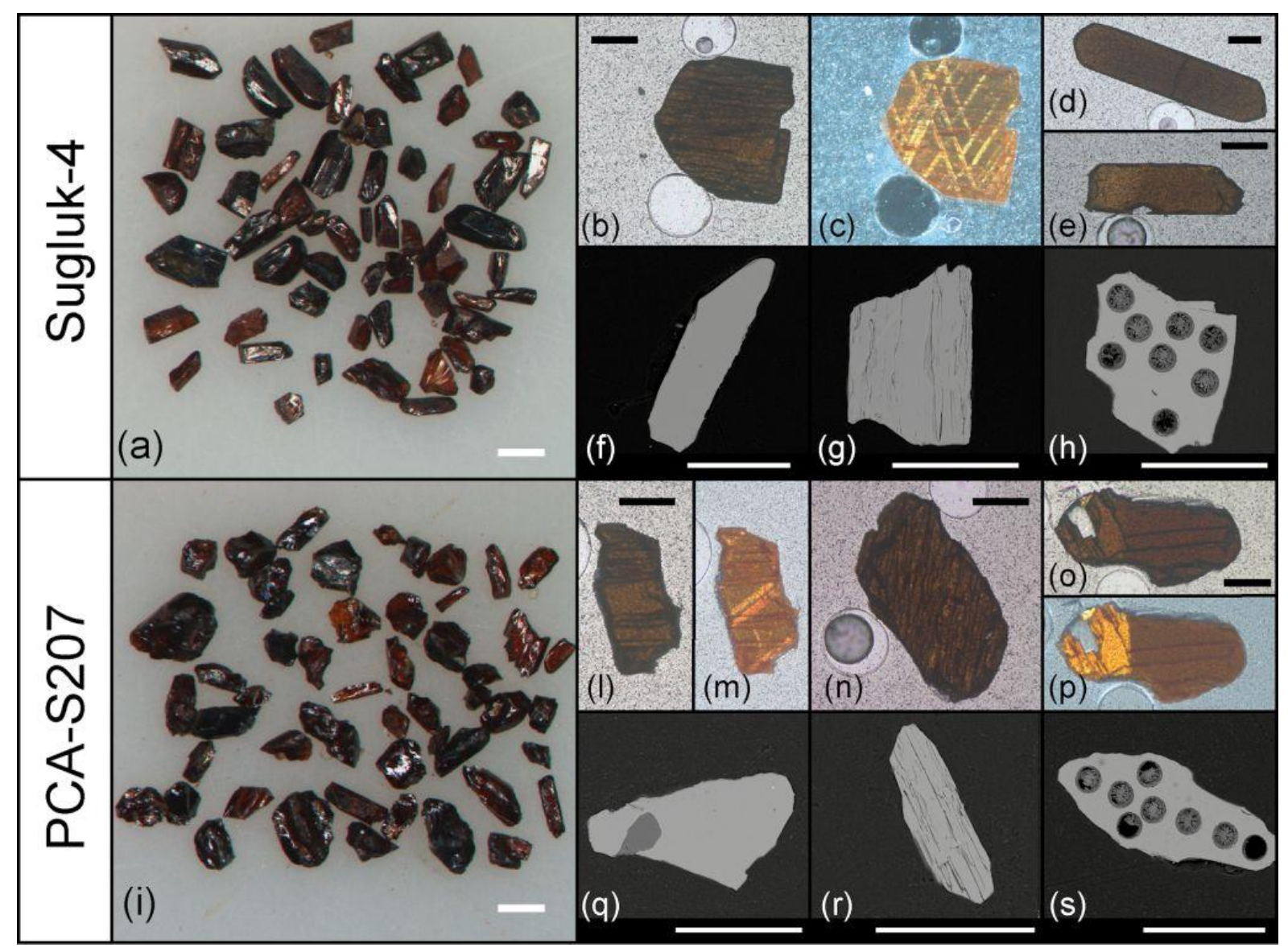

Fig. 1. Images of Sugluk-4 (a to h) and PCA-S207 (i to s) rutile grains. In all images white scale bars are $200 \mu \mathrm{m}$, black scale bars are $100 \mu \mathrm{m}$. Optical microphotographs (b), (d), (e), (l), (n), (o): plane polarised light; (c), (m), (p): crossed polarised light. (f) to (h) and (q) to (s):

BSE images of polished grains; note the darker inclusion in (q) and the ablation pits in (h) and (s) after the measurement of the chemical composition by LA-ICP-MS. 


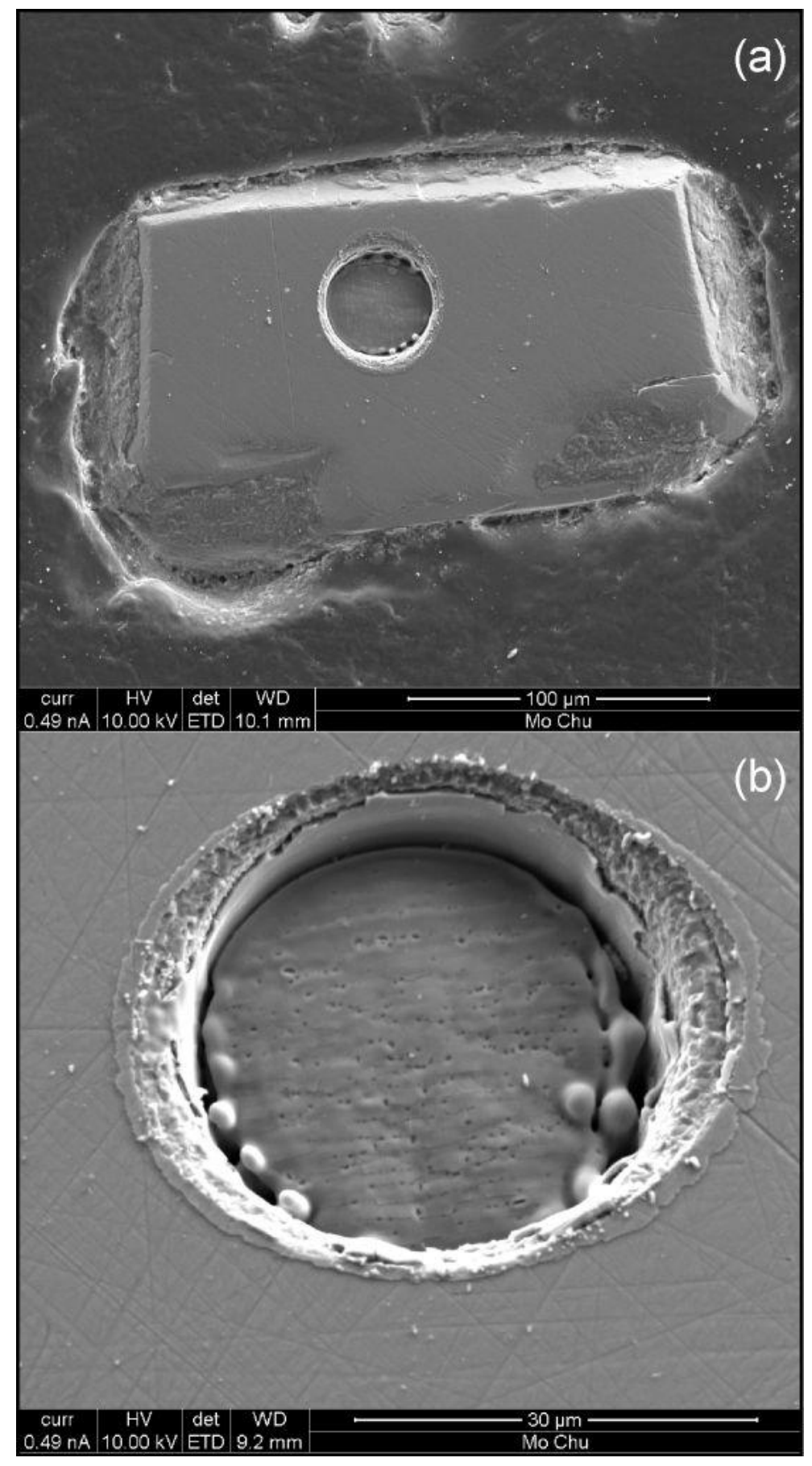

Fig. 2. (a) Secondary electron image of a rutile grain after laser ablation; (b) close up of the ablation pit (diameter $35 \mu \mathrm{m}$, depth $20 \mu \mathrm{m}$; grain tilted on the horizontal plane by $20^{\circ}$ ). 

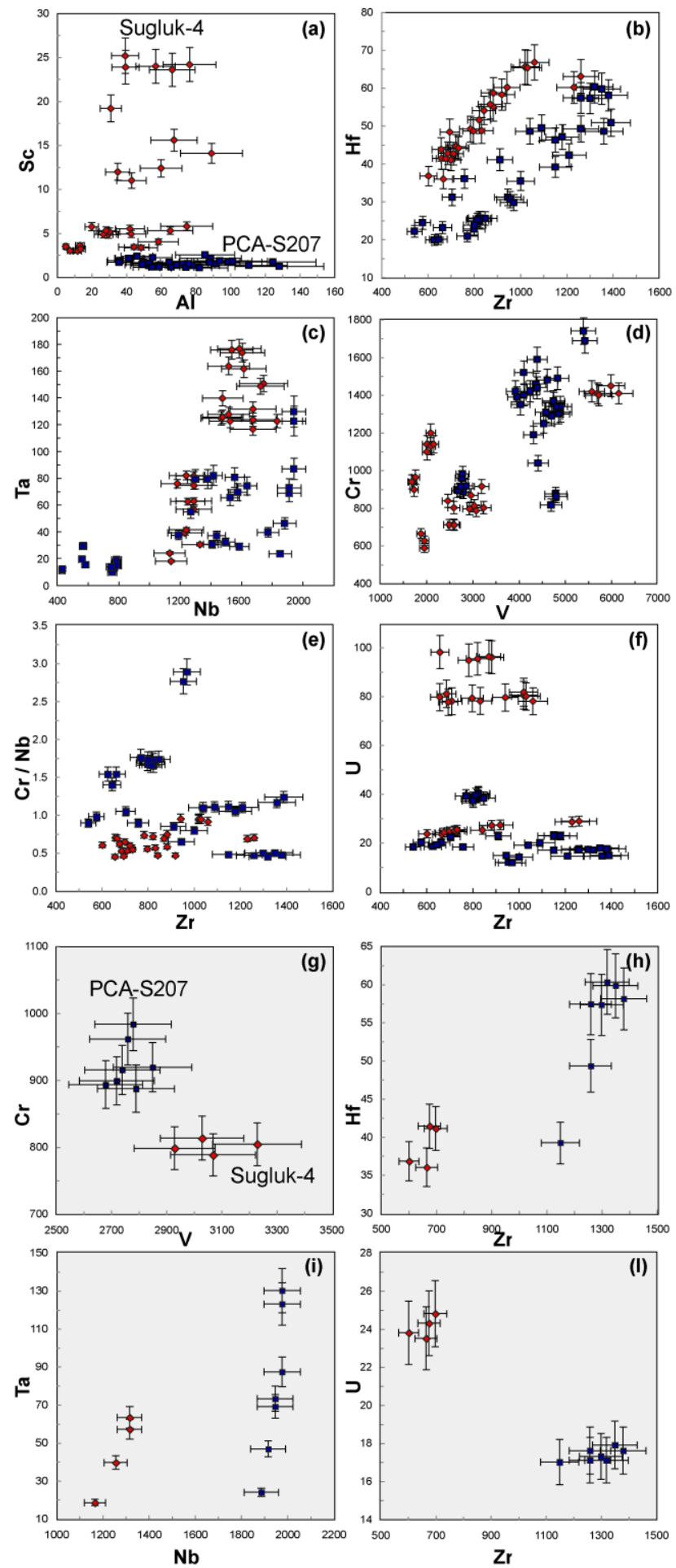

Fig. 3. Trace element composition of Sugluk-4 and PCA-S207 rutile grains determined by LA-quadrupole-ICP-MS. (a) to (f) show the chemical composition of all analysed PCA-S207 (squares) and Sugluk-4 grains (diamonds); (g) to (l) are examples of intragrain composition for PCA-S207 (grain r7, squares) and Sugluk-4 (grain r6, diamonds). All element concentrations are in ppm. Error bars represent the analytical uncertainty \% (1RSD) of each element as indicated in Table 1. 

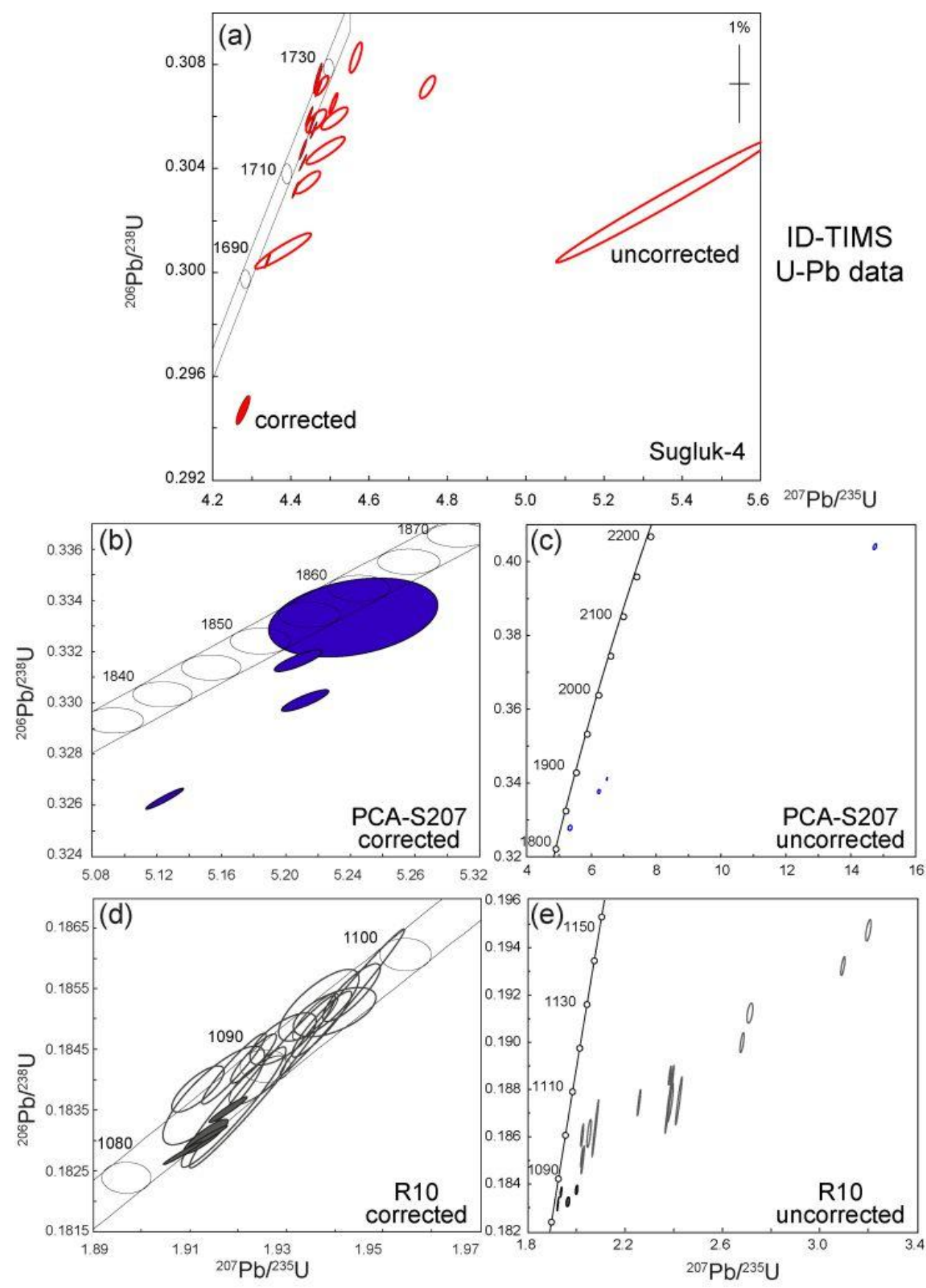

Fig. 4. Wetherill concordia diagrams of Sugluk-4, PCA-S207 and R10 rutile (U-Pb ID-TIMS data). (a) Sugluk-4 U-Pb data corrected (filled ellipses) and uncorrected for common $\mathrm{Pb}$ (open ellipses); PCA-S207 U-Pb data corrected (b) and uncorrected (c) for common Pb; R10 U-Pb data corrected (d) and uncorrected (e) for common $\mathrm{Pb}$. In (d) and (e) data from this work (filled ellipses) are plotted along with the published data (open ellipses) of Luvizotto et al. (2009). The uncorrected ratios in (e) (open ellipses) are calculated from the published radiogenic data of Luvizotto et al., 2009 (see text for details and Table B, supplementary data file). 

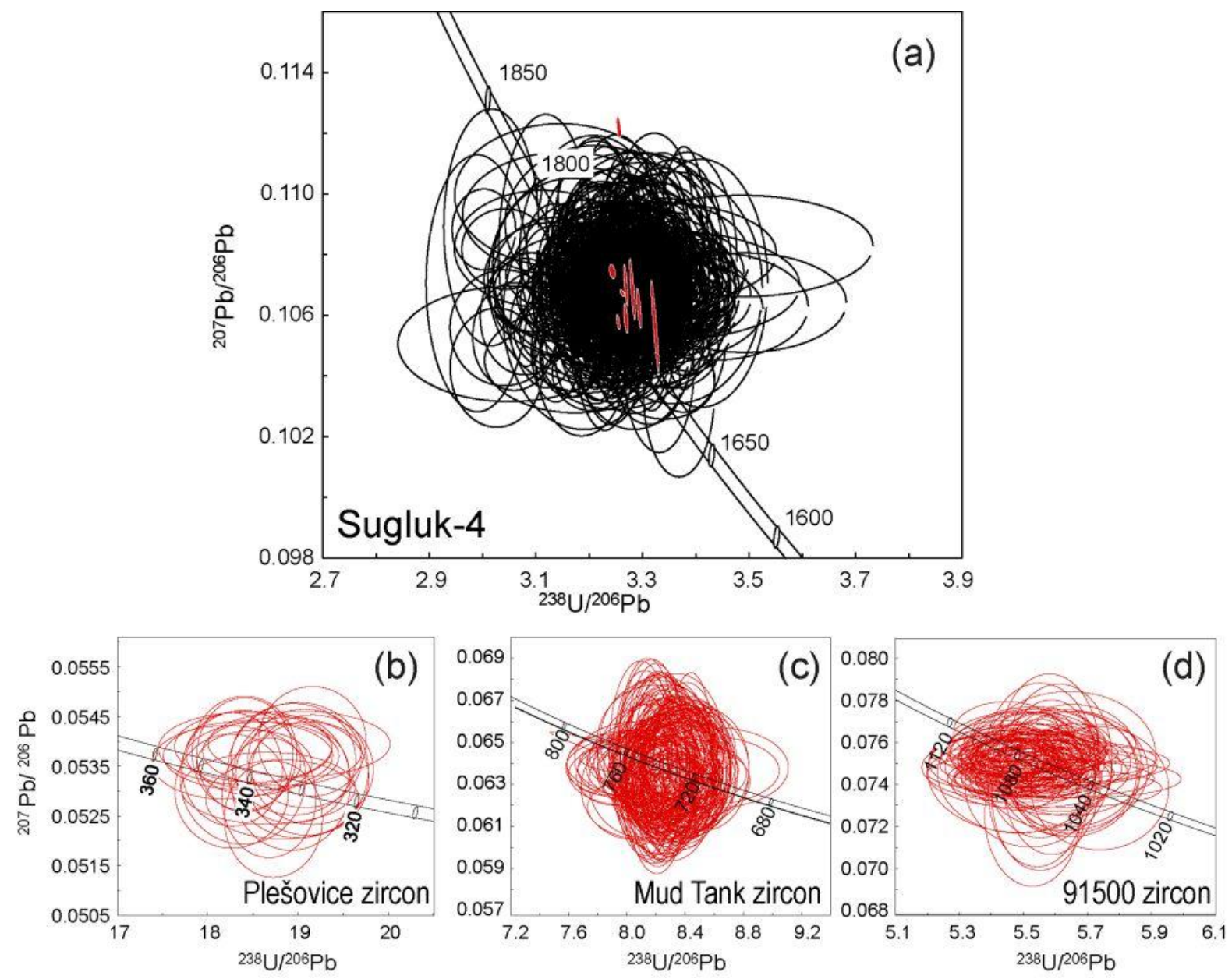

Fig. 5. Tera-Wasserburg diagrams of rutile and zircon reference materials. (a) Sugluk-4 rutile, LA U-Pb data (486 single ablation spots, open ellipses, data acquired over a period of ca. two years) and ID-TIMS data (individual grains, filled ellipses) uncorrected for common $\mathrm{Pb}$. LA $\mathrm{U}-\mathrm{Pb}$ Sugluk-4 data are self-normalised; the uncertainty component related to the normalization factor is not propagated into the individual ${ }^{238} \mathrm{~Pb} /{ }^{206} \mathrm{U}$ data point uncertainty. (b), (c), (d) show the zircon secondary reference materials (Plešovice, Mud Tank and 91500 normalised to GJ1) analysed along with rutile over the same period. 

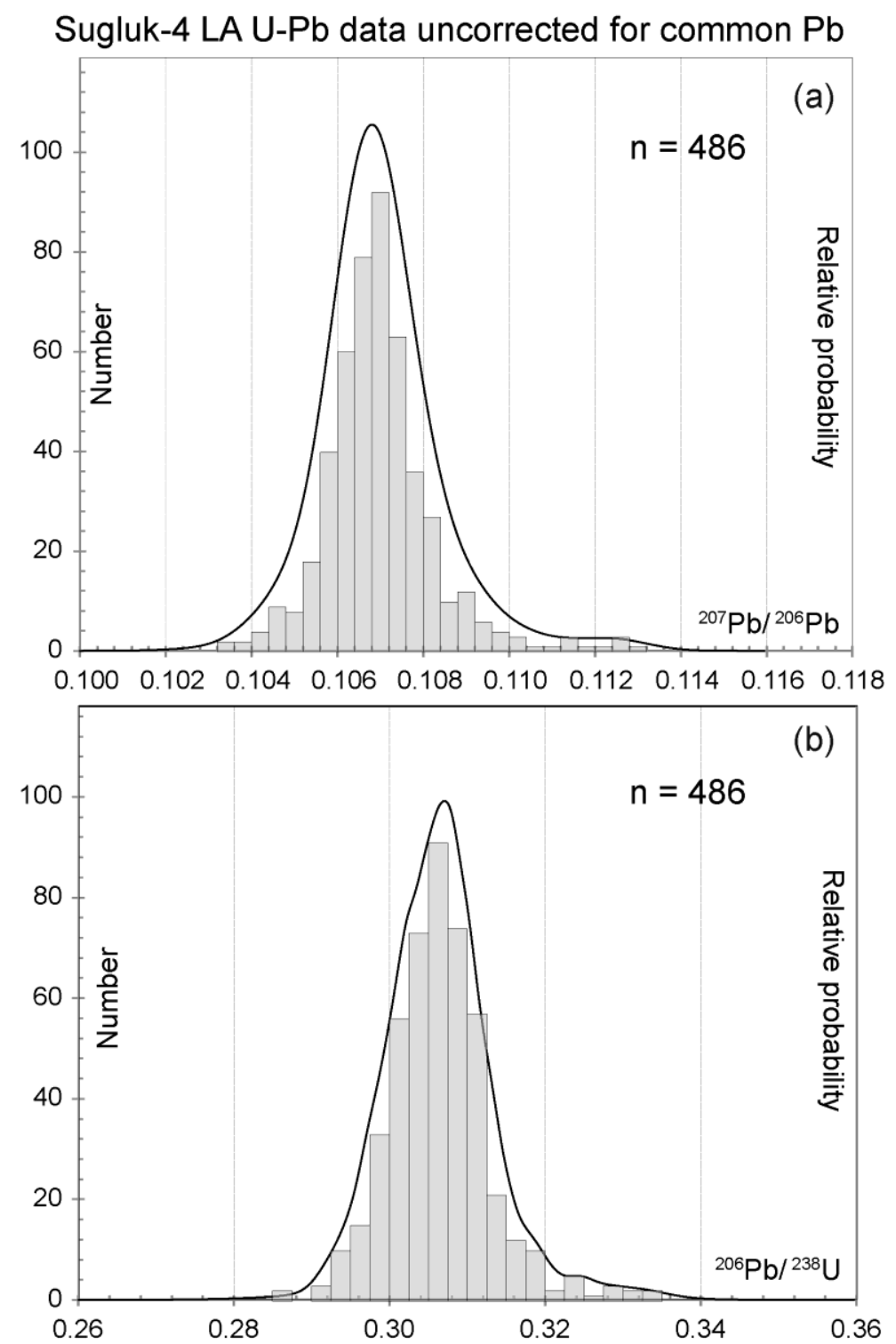

Fig. 6. Probability density plots of Sugluk-4 rutile. (a) ${ }^{207} \mathrm{~Pb} /{ }^{206} \mathrm{~Pb}$ and (b) ${ }^{206} \mathrm{~Pb} /{ }^{238} \mathrm{U}$ ratios, same LA U-Pb data as in Fig. 5a $(\mathrm{n}=486$, uncorrected for common $\mathrm{Pb})$. 

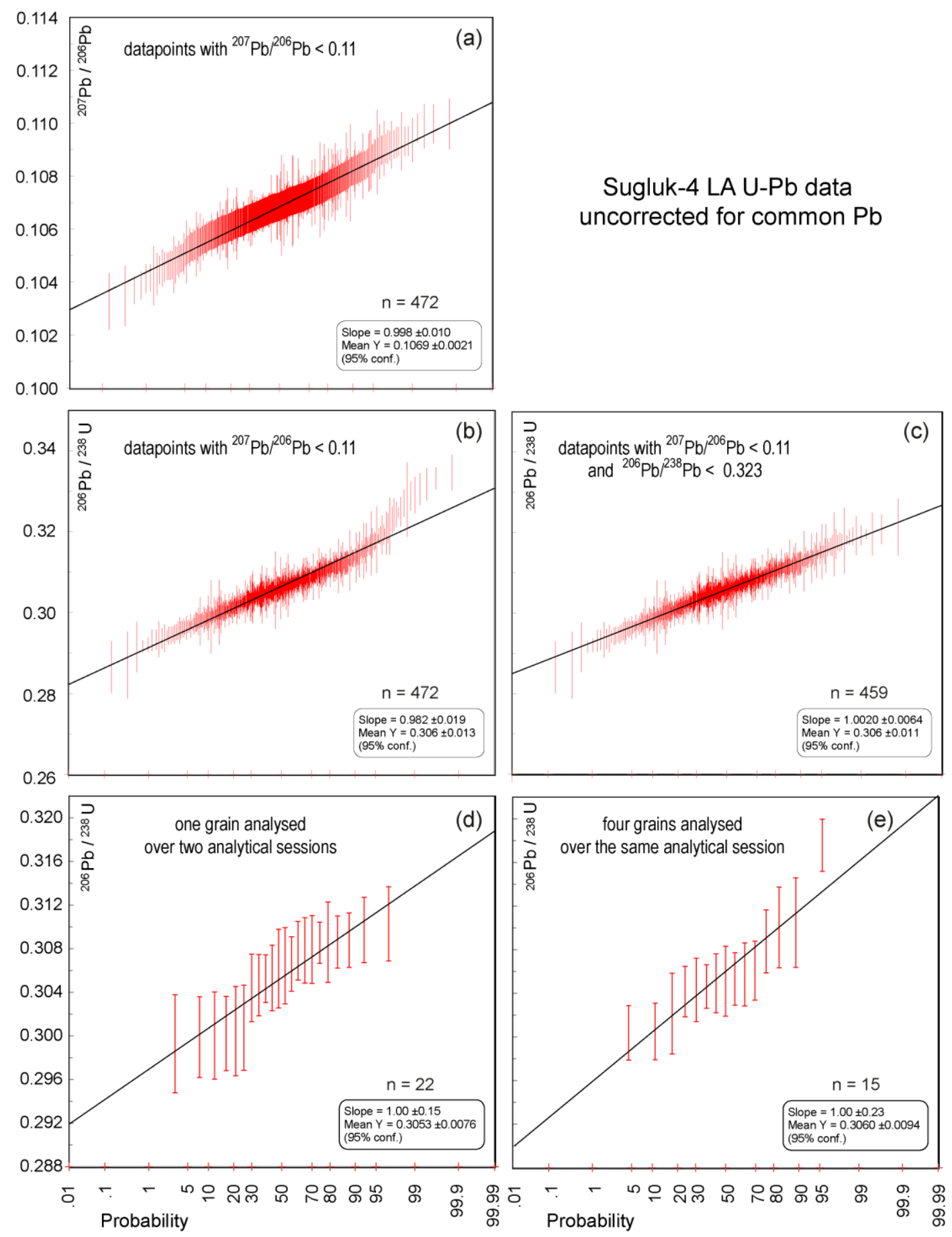

Fig. 7. Linearised probability plots of rutile Sugluk-4. (a) and (b) represent the ${ }^{207} \mathrm{~Pb} /{ }^{206} \mathrm{~Pb}$ and ${ }^{206} \mathrm{~Pb} /{ }^{238} \mathrm{U}$ (b) ratios of 472 datapoints, same data as in Fig. 6 less 14 datapoints with ${ }^{207} \mathrm{~Pb} /{ }^{206} \mathrm{~Pb}>0.11$; (c) represents the same data as in (b), less 13 datapoints with ${ }^{206} \mathrm{~Pb} /{ }^{238} \mathrm{U}>$ $0.323(\mathrm{n}=459)$; (d) shows the ${ }^{206} \mathrm{~Pb} /{ }^{238} \mathrm{U}$ ratios of one grain $(\mathrm{r} 353)$ analysed over two different analytical sessions (22 spot ablations); (e) shows the ${ }^{206} \mathrm{~Pb} /{ }^{238} \mathrm{U}$ ratios of four grains (r301, r302, r303, r304) analysed over the same session (15 spot ablations). In all diagrams data point error symbols are $1 \sigma$. 

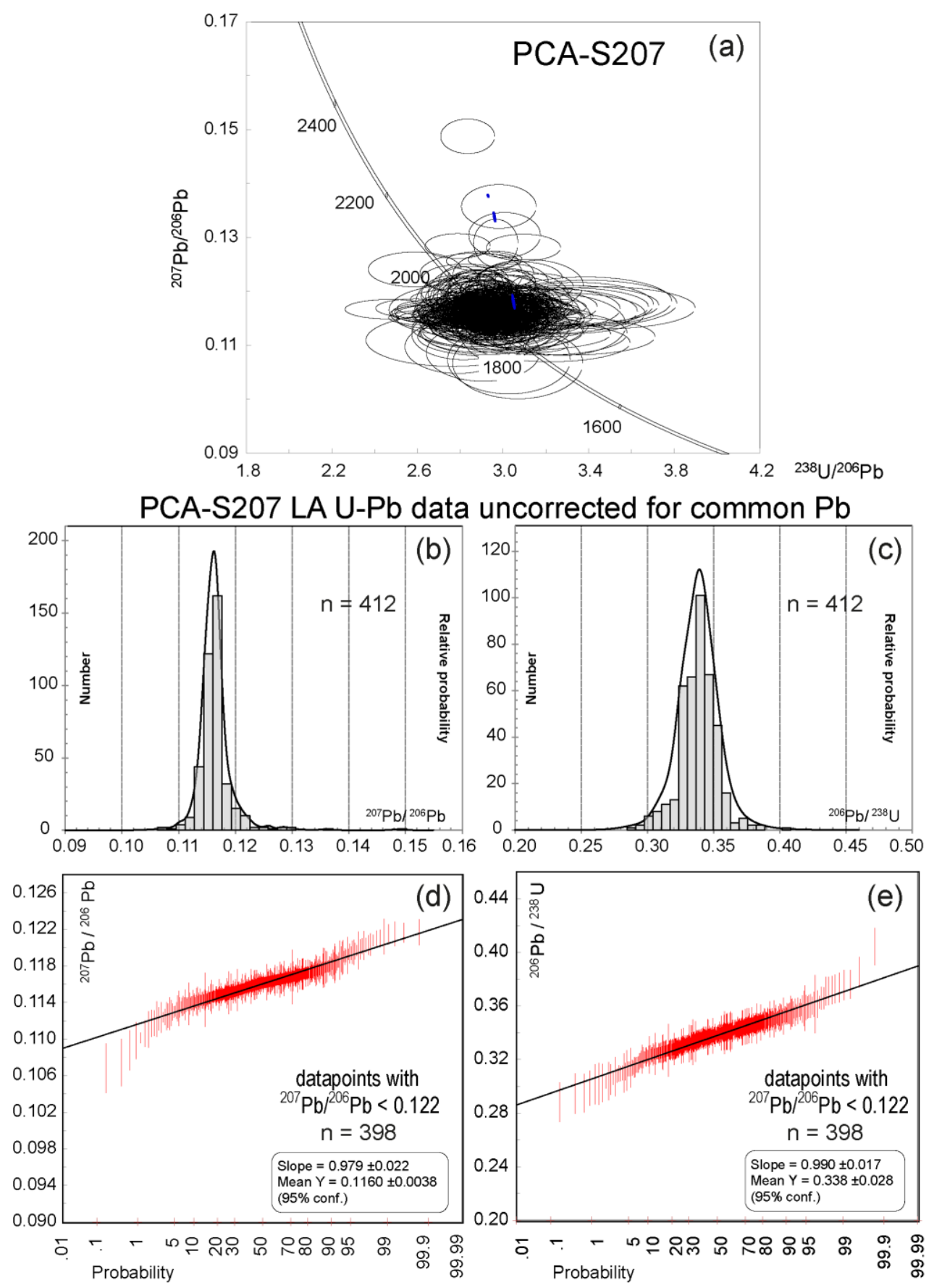

Fig. 8. PCA-S207 U-Pb data. (a) LA U-Pb data normalised to Sugluk-4 plotted as TeraWasserburg diagram (412 single spot ablations, open ellipses) and ID-TIMS data (individual grains, filled ellipses) uncorrected for common $\mathrm{Pb} ;{ }^{207} \mathrm{~Pb} /{ }^{206} \mathrm{~Pb}$ ratios (b) and ${ }^{206} \mathrm{~Pb} /{ }^{238} \mathrm{U}$ (c) ratios plotted as probability density plot, same LA U-Pb data as in (a); (d) and (e) show the ${ }^{207} \mathrm{~Pb} /{ }^{206} \mathrm{~Pb}$ and ${ }^{206} \mathrm{~Pb} /{ }^{238} \mathrm{U}$ ratios as linearised probability plots after the exclusion of 14 datapoints with ${ }^{207} \mathrm{~Pb} /{ }^{206} \mathrm{~Pb}>0.122$. 


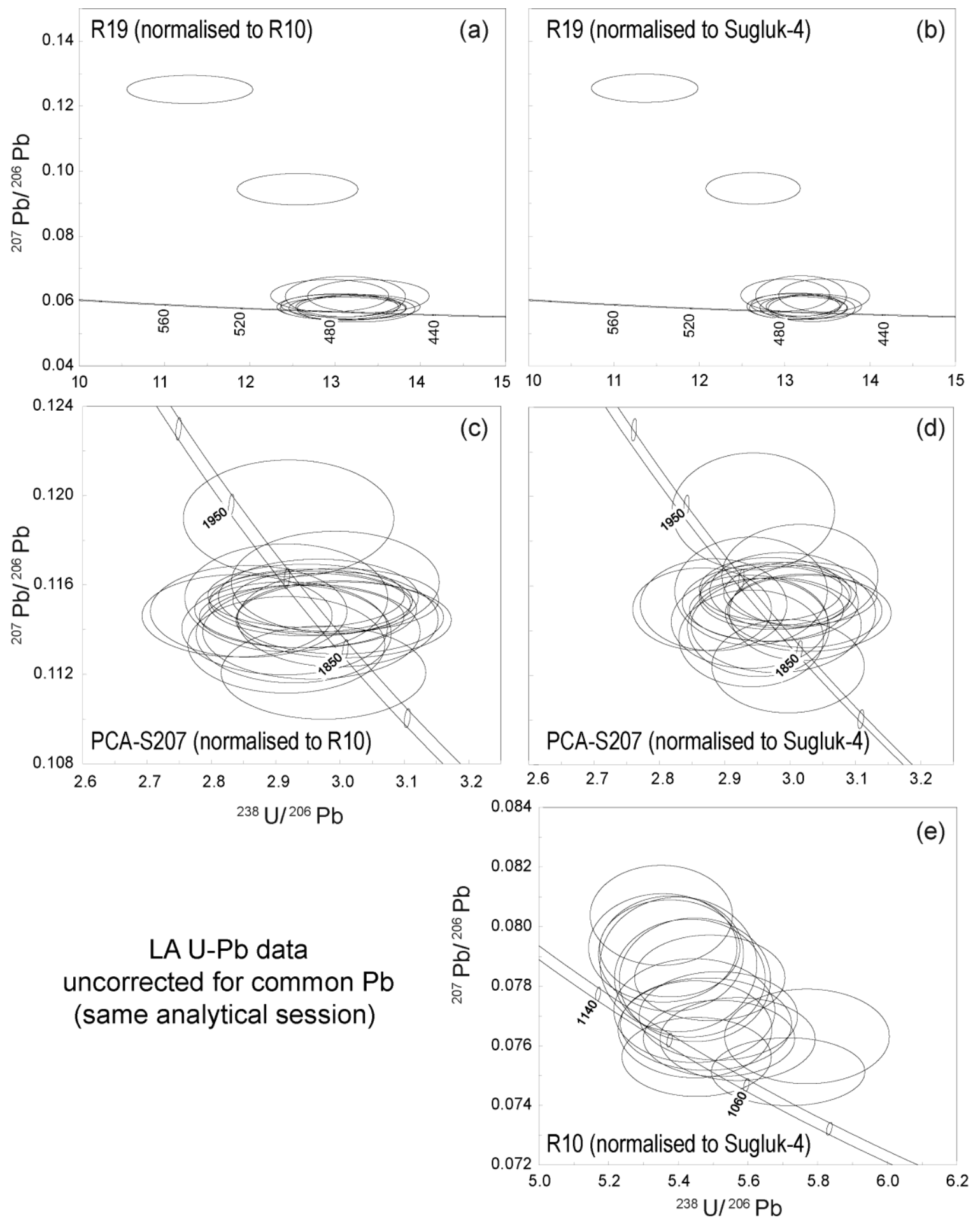

Fig. 9. Tera-Wasserburg plots of rutiles R19 (11 datapoints), PCA-S207 (20 datapoints from 3 grains) and R10 (17 datapoints). (a) R19 normalised to R10 (average of isotopic ratios from this work); (b) R19 normalised to Sugluk-4; (c) PCA-S207 normalised to R10 (average of isotopic ratios from this work); (d) PCA-S207 normalised to Sugluk-4; (e) R10 normalised to Sugluk-4. All LA U-Pb data uncorrected for common $\mathrm{Pb}$ and obtained during the same analytical session. 


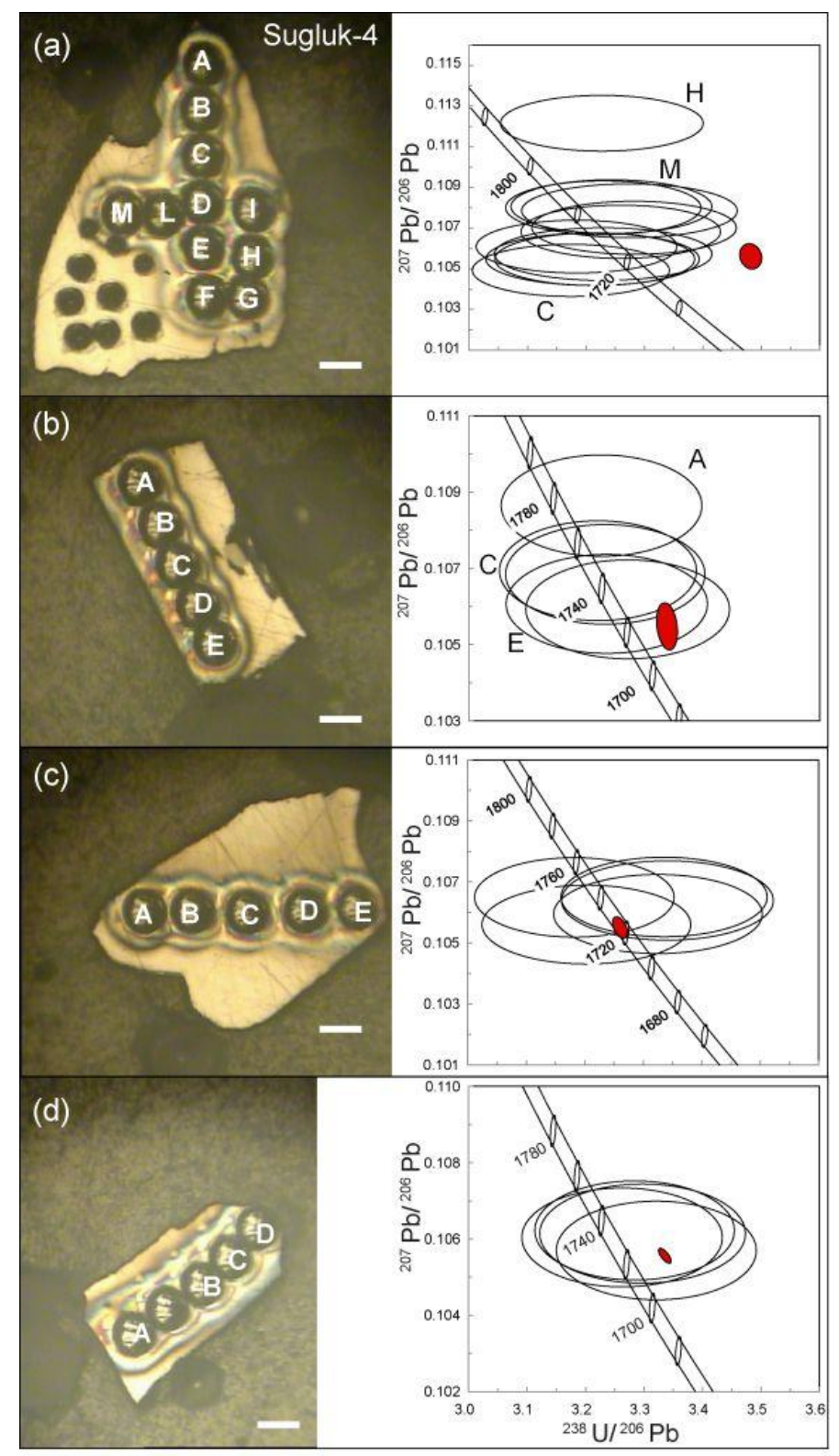

Fig. 10. Tera-Wasserburg diagrams of Sugluk-4 rutile grains analysed by both ID-TIMS (filled ellipses) and LA-MC-ICP-MS (open ellipses), the latter normalised to R10; the U-Pb ID-TIMS data are corrected for common $\mathrm{Pb}$. The weighted average of the ${ }^{207} \mathrm{~Pb} /{ }^{206} \mathrm{~Pb}$ dates (LA data) is: $1741 \pm 14 \mathrm{Ma}$, grain $\mathrm{r} 1$ (a); $1747 \pm 23$, grain r2 (b); $1735.0 \pm 8.6$, grain r3 (c); $1732.2 \pm 4.5$ grain $\mathrm{r} 4(\mathrm{~d})$, while the ${ }^{207} \mathrm{~Pb} /{ }^{206} \mathrm{~Pb}$ ID-TIMS date for each grain is $1726.6 \pm 8.7$ $\mathrm{Ma}(\mathrm{r} 1), 1724.4 \pm 8.5 \mathrm{Ma}(\mathrm{r} 2), 1723.7 \pm 4.9 \mathrm{Ma}(\mathrm{r} 3)$ and $1723.8 \pm 2.8(\mathrm{r} 4)$. Grain $\mathrm{r} 1$ shows the larger scatter of ratios, and includes one of the 14 datapoints (spot $\mathrm{H}$ ) with the highest relative common $\mathrm{Pb}$ content of the whole dataset (positive tail of the probability density distribution of Fig. 6). In all images the white scale bar is $50 \mu \mathrm{m}$. 

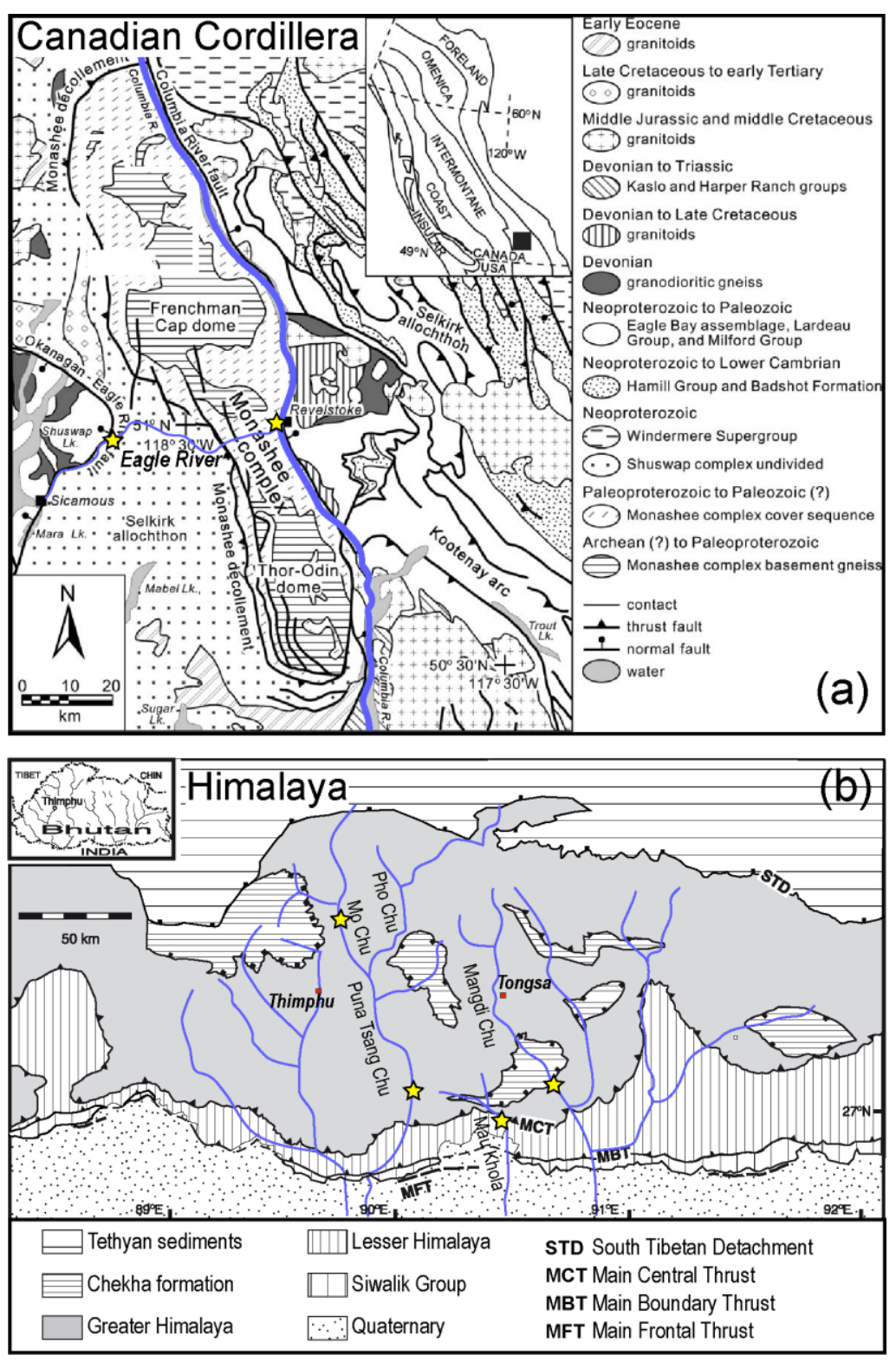

Fig. 11. Schematic geological maps of a portion of the Canadian Cordillera in British Columbia (a) and of the Bhutan Himalaya (b). Stars indicate the location of detrital rutile samples from modern rivers. Maps modified after Crowley and Parrish (1999) and Hollister and Grujic (2006). 


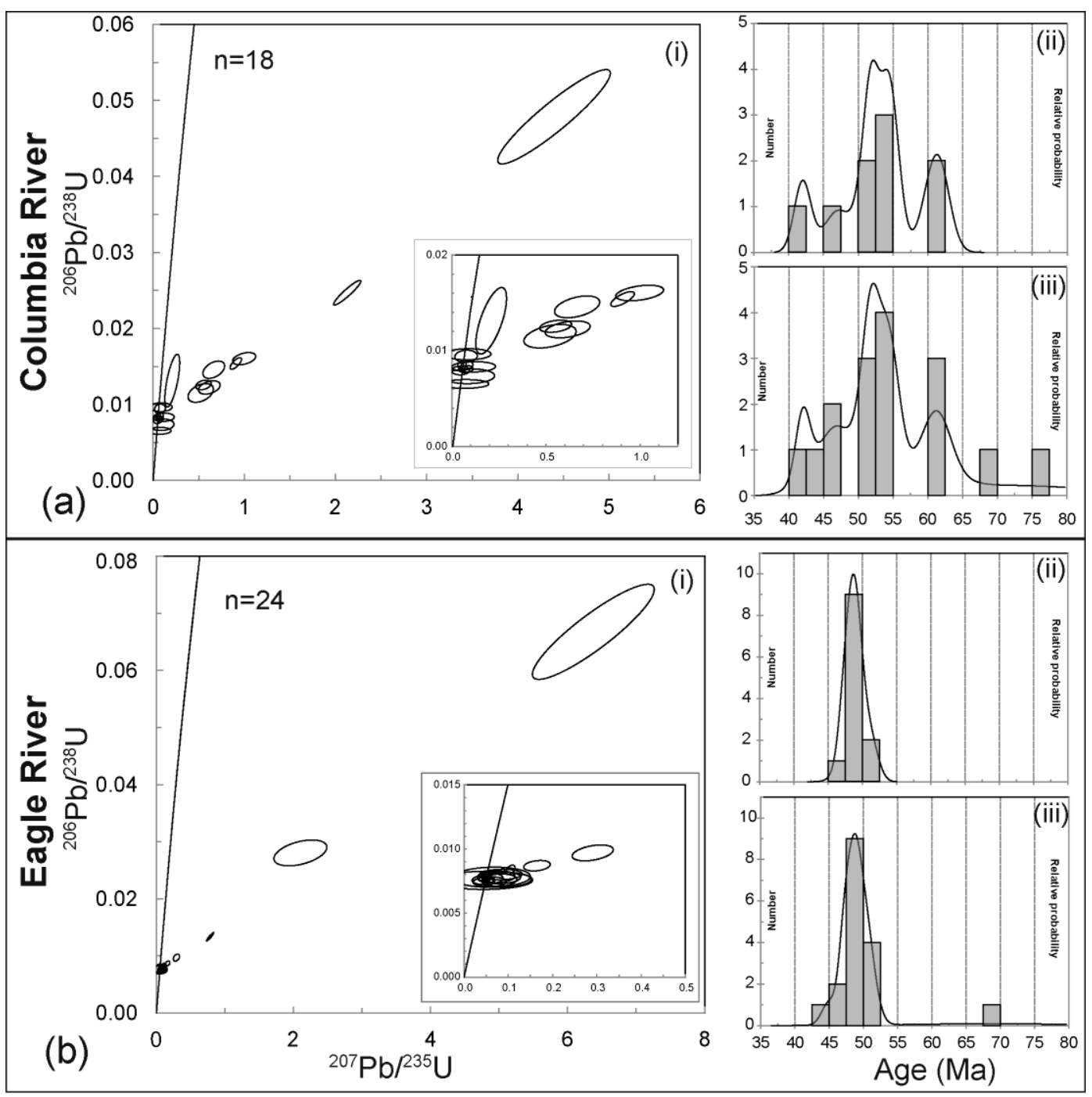

Fig. 12. U-Pb data of detrital rutile samples from British Columbia. (a) and (b) are samples BC-04g66 (Columbia River) and BC-04g67 (Eagle River) respectively, represented as Concordia diagrams (i) and as probability density plots $\left({ }^{206} \mathrm{~Pb} /{ }^{238} \mathrm{U}\right.$ dates) of the concordant datapoints only (ii) and the concordant plus the originally discordant datapoints after projection (iii) as explained in the text. All data not corrected for common $\mathrm{Pb}$ and normalised to Sugluk-4. 


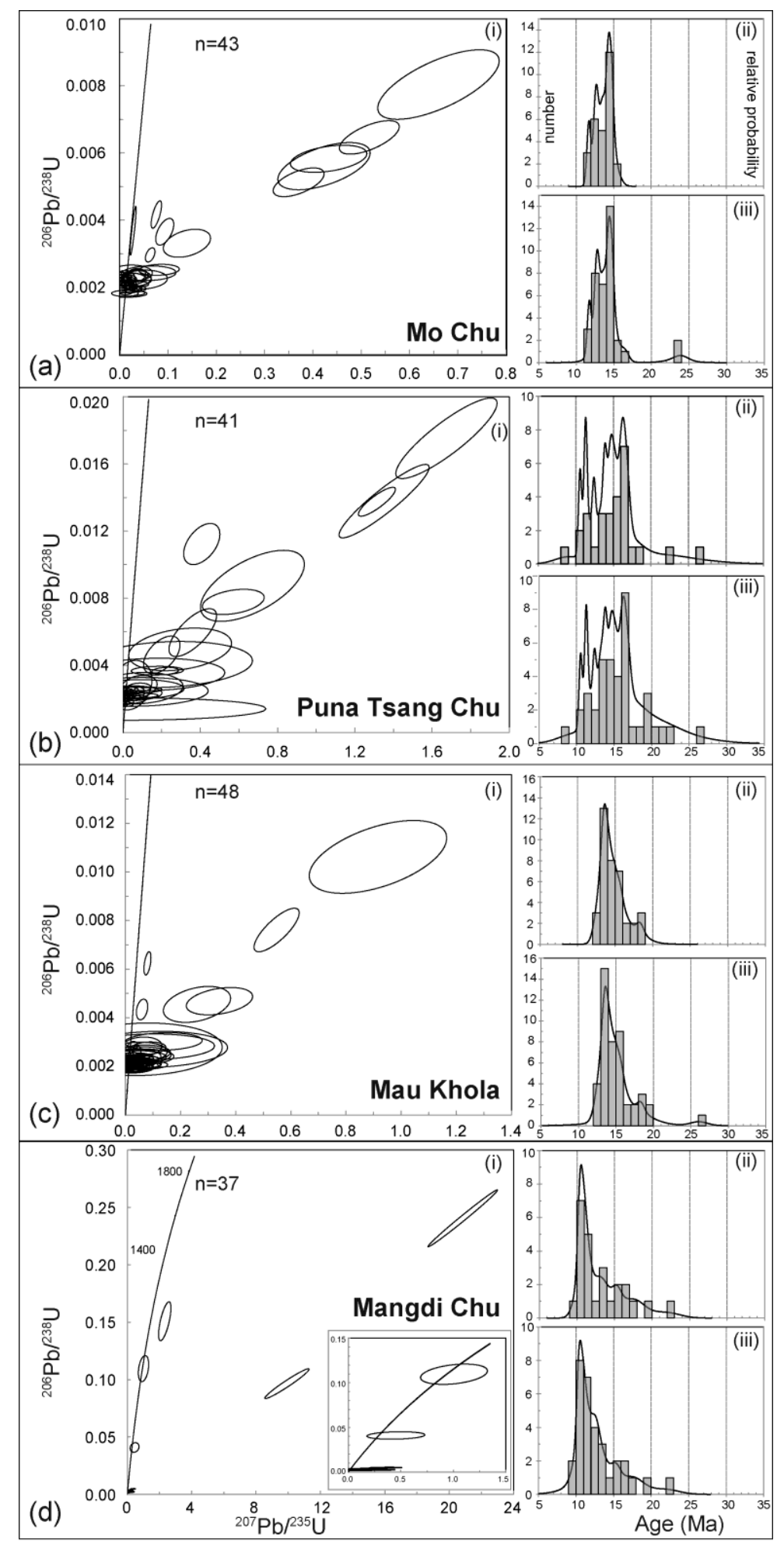

Fig. 13. U-Pb data of detrital rutile samples from Bhutan. (a), (b), (c) and (d) are samples BH0108 (Mo Chu), LB09-03 (Puna Tsang Chu), LB09-02 (Mau Khola) and LB09-01 (Mangdi Chu). The data are represented as Concordia diagrams (i) and as probability density plots $\left({ }^{206} \mathrm{~Pb} /{ }^{238} \mathrm{U}\right.$ dates$)$ of the concordant datapoints only (ii) and the concordant plus the originally discordant datapoints after projection (iii) as explained in the text. All data not corrected for common $\mathrm{Pb}$ and normalised to Sugluk-4. 
Supplementary file

\section{Geological and thermochronological setting of Sugluk-4 and PCA-S207}

Sugluk-4 and PCA-S207 are a granulite facies quartzite from the Ungava segment of the Trans-Hudson orogen of Canada (the northern Cape Smith Belt of Quebec) and a highly strained granulite facies paragneiss from the Snowbird Tectonic Zone (East Lake Athabasca region, Sasatchewan, Canada). Many of the Paleoproterozoic orogenic belts of Canada represent collision zones between Archean provinces that amalgamated between 2.0 and 1.8 $\mathrm{Ga}$ (Hoffman, 1988). One of the main crustal-scale features of the Canadian Shield is the Snowbird tectonic zone, a high amplitude linear anomaly in the horizontal gradient map of the Canadian Shield (Fig. 1 of Martel et al., 2008), which has been interpreted either as a Paleoproterozoic suture reflecting the $<1.9$ Ga collision of the Rae and Hearne Archean provinces or an intracontinental Archean shear zone with only limited Paleoproterozoic reworking (Hoffman, 1988; Hanmer et al., 1995). Recent work in this area documented the importance of $1.9 \mathrm{Ga}$ metamorphism and subsequent exhumation of deep-crustal rocks (Baldwin et al., 2004; Mahan et al., 2006; Flowers et al., 2006a; 2008; Martel et al., 2008; Dumond et al., 2008). The East Lake Athabasca region spans the central segment of the Snowbird tectonic zone, and exposes a broad area of high $\mathrm{P}$ granulites $(1.0$ to $>1.5 \mathrm{GPa}$ and $>$ $\left.750^{\circ} \mathrm{C}\right)$. The region has been effectively shielded from major perturbation since the Proterozoic. PCA-S207 is from the southern domain (Fig. 2 of Flowers et al. 2006a; cf. "upper deck" of Hanmer et al., 1994) of the East Atabasca Mylonite triangle, a region exhumed between the $\sim 1.9 \mathrm{Ga}$ high-pressure granulite facies metamorphism and the $\sim 1.7 \mathrm{Ga}$ unconformable deposition of Athabasca basin sediments on the exhumed rocks, as constrained by synkinematic monazite from shear zones dated at 1.85 Ga (Mahan et al., 2006; Flowers et al., 2006a). Single grain ID-TIMS U-Pb thermochronological data in the range 1.7-1.8 Ga have been obtained for titanite, apatite and rutile from the different lithotectonic domains of the East Lake Athabasca region, reflecting cooling through temperatures of 650-450 ${ }^{\circ} \mathrm{C}$ (Baldwin et al., 2004; Flowers et al., 2006a). ${ }^{40} \mathrm{Ar} /{ }^{39} \mathrm{Ar}$ muscovite and biotite dates from $1.78 \pm 0.01$ to $1.72 \pm 0.01 \mathrm{Ga}$ and $(\mathrm{U}-\mathrm{Th}) / \mathrm{He}$ zircon dates from $1.73 \pm 0.01$ to 1.72 $\pm 0.01 \mathrm{Ga}$ record final cooling through $350-300^{\circ} \mathrm{C}$ and $<180^{\circ} \mathrm{C}$, respectively (Flowers et al., 2006a, 2006b).

Within the Canadian Shield, the Trans-Hudson orogen is the most completely preserved Paleoproterozoic collisional belt formed between 2.0 and $1.8 \mathrm{Ga}$ ago following the closure of the Manikewan Ocean that was interposed between the Rae craton and the Superior craton 
(Hofmann, 1988; St-Onge et al., 2001; Corrigan et al., 2009). The Ungava segment of this orogen is $\mathrm{a} \sim 400 \mathrm{~km}$ long belt preserving metaplutonic and metasedimentary thrust sheets (the Narsajuaq arc and Cape Smith belt, Fig. 1 of St-Onge et al., 2000) accreted to the Archean rocks of the Superior craton to the south (Lucas et al., 1992; Machado et al., 1993). In the vicinity of Sugluk Inlet on the north coast of the Ungava peninsula (Fig. 1 of Parrish, 1989) a sheared tectonic assemblage of igneous and metasedimentary rocks belonging to the Narsajuaq arc and Sugluk Group occurs at granulite facies conditions, with peak pressures of $\sim 7-8 \mathrm{kbar}$ and at $>800^{\circ} \mathrm{C}$ (St-Onge et al., 2000). Turbiditic sedimentary rocks and the Sugluk-4 quartzite from this location yielded an assemblage of detrital zircons ranging in age from 1833-1840 Ma and 1832-1834 Ma respectively, as well as Archean zircons (ID-TIMS U-Pb data: Parrish 1989; Parrish and Noble, 2003). These zircons are interpreted as derived from the 1.82-1.84 Ga plutonic rocks of the Narsajuaq arc. Metamorphic overgrowths at 1825-1829 Ma on zircon cores older than $2230 \mathrm{Ma}$ in a garnet-bearing orthogneiss relate to the granulite facies metamorphism accompanied by strong deformation that followed the deposition of the sedimentary rocks. A few Sugluk-4 concordant zircon rim U-Pb dates as young as $1813 \pm 9$ Ma have also been recently obtained by LA-MC-ICP-MS (Bracciali, unpublished data). Monazite and xenotime from sample Sugluk-3 (a garnet-bearing orthogneiss) $1815-1820 \mathrm{Ma}$ and $1792 \mathrm{Ma}$ old suggest a protracted period of slow-cooling from high metamorphic grade to at least $1758 \mathrm{Ma}$, the age of igneous zircons from a granitic dyke cross-cutting all the elements of the orogen.

\section{References}

Baldwin, J.A., Bowring, S.A., Williams, M.L. and Williams, I.S., 2004. Eclogites of the Snowbird tectonic zone: petrological and U-Pb geochronological evidence for Paleoproterozoic high-pressure metamorphism in the western Canadian Shield. Contributions to Mineralogy and Petrology 147, 528-548.

Corrigan, D., Pehrsson, S., Wodicka, N. and de Kemp, E., 2009. The Palaeoproterozoic Trans-Hudson Orogen: a prototype of modern accretionary processes. Geological Society, London, Special Publications 327, 457-479.

Dumond, G., McLean, N., Williams, M.L., Jercinovic, M.J. and Bowring, S.A., 2008. Highresolution dating of granite petrogenesis and deformation in a lower crustal shear zone: Athabasca granulite terrane, western Canadian Shield. Chemical Geology 254, 175-196.

Flowers, R.M. et al., 2006a. Multistage exhumation and juxtaposition of lower continental crust in the western Canadian Shield: Linking high-resolution U-Pb and ${ }^{40} \mathrm{Ar} /{ }^{39} \mathrm{Ar}$ thermochronometry with pressure-temperature-deformation paths. Tectonics 25 , TC4003. 
Flowers, R.M., Bowring, S.A., Reiners, P.W., 2006b. Low long-term erosion rates and extreme continental stability documented by ancient (U-Th)/He dates. Geology 34, 925928.

Flowers, R., Bowring, S., Mahan, K., Williams, M., Williams, I., 2008. Stabilization and reactivation of cratonic lithosphere from the lower crustal record in the western Canadian shield. Contributions to Mineralogy and Petrology 156, 529-549.

Hanmer, S., Parrish, R., Williams, M. and Kopf, C., 1994. Striding-Athabasca mylonite zone: Complex Archean deep-crustal deformation in the East Athabasca mylonite triangle, northern Saskatchewan. Canadian Journal of Earth Sciences 31, 1287-1300.

Hanmer, S., Williams, M. and Kopf, C., 1995. Modest movements, spectacular fabrics in an intracontinental deep-crustal strike-slip fault: Striding-Athabasca mylonite zone, NW Canadian Shield. Journal of Structural Geology 17, 493-507.

Hoffman, P.F., 1988. United Plates of America, The Birth of a Craton: Early Proterozoic Assembly and Growth of Laurentia. Annual Review of Earth and Planetary Sciences 16, 543-603.

Lucas, S.B., St-Onge, M.R., Parrish, R.R. and Dunphy, J.M., 1992. Long-lived continentocean interaction in the Early Proterozoic Ungava orogen, northern Quebec, Canada. Geology 20, 113-116.

Machado, N., David, J., Scott, D.J., Lamothe, D., Philippe, S. and Gariépy, C., 1993. U-Pb geochronology of the western Cape Smith Belt, Canada: new insights on the age of initial rifting and arc magmatism. Precambrian Research 63, 211-223.

Mahan, K., Williams, M., Flowers, R., Jercinovic, M., Baldwin, J. and Bowring, S., 2006. Geochronological constraints on the Legs Lake shear zone with implications for regional exhumation of lower continental crust, western Churchill Province, Canadian Shield. Contributions to Mineralogy and Petrology 152, 223-242.

Martel, E., van Breemen, O., Berman, R.G. and Pehrsson, S., 2008. Geochronology and tectonometamorphic history of the Snowbird Lake area, Northwest Territories, Canada: New insights into the architecture and significance of the Snowbird tectonic zone. Precambrian Research 161, 201-230.

Parrish, R.R., 1989. U-Pb geochronology of the Cape Smith Belt and Sugluk block, northern Quebec. 1989.

Parrish, R.R. and Noble, S.R., 2003. Zircon U-Pb geochronology by isotope dilution thermal ionisation mass spectrometry (ID-TIMS). In: J.M. Hanchar and P.W.O. Hoskin (Eds.): Reviews in Mineralogy and Geoschemistry. Mineralogical Society of America and Geochemical Society., pp. 183-213. 
St-Onge, M.R., Wodicka, N. and Lucas, S.B., 2000. Granulite- and amphibolite-facies metamorphism in a convergent-plate-margin setting: synthesis of the Quebec-Baffin segment of the Trans-Hudson Orogen. The Canadian Mineralogist 38, 379-398.

St-Onge, M.R., Scott, D.J. and Wodicka, N., 2001. Terrane boundaries within Trans-Hudson Orogen (Quebec-Baffin segment), Canada: changing structural and metamorphic character from foreland to hinterland. Precambrian Research 107, 75-91. 